SALINERO, Sebastián. "La expulsión de extranjeros en el derecho penal. Una realidad en España, una posibilidad en Chile".

Polít. crim. Vol. 6, № 11 (Julio 2011), Art. 4, pp. 106 - 141.

[http://www.politicacriminal.cl/Vol_06/n_11/Vol6N11A4.pdf]

\title{
La Expulsión de Extranjeros en el Derecho Penal. Una realidad en España, una posibilidad en Chile.*
}

\author{
Sebastián Salinero Echeverría** \\ Investigador Universidad de Talca \\ ssalineroecheverria@gmail.com
}

\section{Resumen}

El artículo analiza desde un prisma jurídico penal critico la institución de la expulsión de extranjeros, la cual se ha instalado de manera novedosa en el proyecto de ley impulsado en Chile, tendiente a modificar la Ley $\mathrm{N}^{\mathrm{o}}$ 18.216, sobre medidas alternativas a las penas privativas o restrictivas de libertad. El autor identifica y compara esta institución con la existente en el Derecho penal español desde el año 1995, la cual sitúa como fuente directa de su generación (u origen); describe y aprecia su historia, su naturaleza jurídica, su ámbito de aplicación, sus efectos legales y sus posibles fines político criminal. Finalmente, realiza una serie de conclusiones de carácter crítico y se manifiesta contrario al proyecto legislativo.

\section{Palabras clave}

Expulsión, extranjeros, Chile, España, residencia legal.

\begin{abstract}
This article analyzes -from a criminal law perspective- the establishment of the expulsion of foreigners, which has been installed in a new way in the bill amending Law $\mathrm{N}^{\circ} 18.216$, regarding alternative measures to imprisonment. The author identifies and compares this establishment with the current one in the Spanish Criminal Law of 1995, which he considers as a direct source; he also describes and appreciates the history of this establishment, its legal nature, scope, legal purposes, and its possible criminal policy aims. Finally, he draws a series of critical conclusions on the expulsion of foreigners.
\end{abstract}

\section{Key words}

Expulsion, foreigners, Chile, Spain, legal residence.

\section{Introducción}

Chile un país de poco más de 17 millones de habitantes, ${ }^{1}$ cuenta con una incipiente y pujante inmigración dada su solidez económica en la región y la apertura de sus

\footnotetext{
" Este artículo se apoya en otro inédito del mismo autor, denominado "La expulsión de extranjeros en el Código Penal español", el que fue presentado para obtener la suficiencia investigadora.

** Abogado, Magíster en Derecho Penal de la U. de Talca, Becario Jade Plus (Banco Santander) y recientemente recibió Diploma de Estudios Avanzados en la U. de Lérida (España). Además pertenece al Grupo de Investigación Sistema de Justicia Penal de esa casa de estudios.
} 
SALINERO, Sebastián. "La expulsión de extranjeros en el derecho penal. Una realidad en España, una posibilidad en Chile".

fronteras sin restricciones. Según el último informe de la Organización Internacional para las Migraciones, Chile pasó de tener 177.000 inmigrantes en el año 2000 a más de 231.000 en 2005. ${ }^{2}$ Sin embargo, el Departamento de Extranjería y Migración contabilizó 352.344 personas a diciembre de 2009. ${ }^{3}$ El crecimiento inmigratorio entre los años 2000 y 2009 se ha duplicado, es el más alto que ha experimentado la región. ${ }^{4}$

Por su parte, España es un país multicultural, multirracial, plurireligioso, plurilingüistico, ${ }^{5}$ donde los extranjeros regulares que residen, alcanzaron en el año 2008 algo más de 4 millones cuatrocientas mil personas. ${ }^{6}$ Desde el año 1998 al 2008, se reporta un incremento de la tasa de inmigrantes regulares en el orden del $520 \%$. Si a estas cifras oficiales, sumamos el contingente de inmigrantes irregulares o también llamados "sin papeles", los cuales se sitúan en cifras cercanas a 300.000 personas, tenemos como resultado que más del $11 \%$ de las personas que habitan España son inmigrantes. $^{7}$

Sin duda, los inmigrantes en su conjunto -regulares o no-, y sea cualquiera el país donde estén situados, son un colectivo que contribuye de distintas maneras en las diversas áreas de la sociedad, sean laborales, culturales, educacionales, etc. No obstante ello, en el caso de España, el ordenamiento jurídico penal reacciona frente a estos sujetos, o mejor dicho frente al grupo de los que no tienen residencia legal, con la medida de la expulsión, la cual opera no sólo de manera desigualitaria o desproporcional, sino que restándole valor a la vigencia de la norma penal y, sobre todo, en desprecio de la víctima del delito y del bien jurídico protegido por el Derecho.

Por su parte, el Gobierno de Chile mediante una indicación al Proyecto de Ley tendiente a modificar la Ley $\mathrm{N}^{\mathrm{o}}$ 18.216, sobre medidas alternativas a las penas privativas $\mathrm{o}$ restrictivas de libertad (en adelante, el PLMMA), quiere recoger, malamente a nuestro juicio, en el ordenamiento jurídico penal chileno la institución de la expulsión de extranjeros sin residencia legal. ${ }^{8}$

\footnotetext{
${ }^{1}$ Instituto Nacional de Estadística (2007). «Compendio estadístico de Chile 2006». En http://www.ine.cl, (Consultado el 12/09/2010).

${ }_{2}$ Organización Internacional para las Migraciones. En: http://www.iom.int/jahia/Jahia/lang/es/pid/1. (Consultado el 12/09/2010).

${ }^{3}$ Informe de Permisos Otorgados y Estimación de población de extranjeros en Chile a diciembre de 2009. Fuente: Departamento de Extranjería y Migración (DEM)-Ministerio del Interior. En http://www.extranjeria.gov.cl/estadisticas mig.html (Consultado el 12/09/2010).

${ }^{4}$ La Tercera de 24/05/2009 (Prensa).

${ }^{5}$ Cfr. SAGARRA TRÍAS, Eduard, "Un nuevo Status de extranjero en España (el inmigrante, irregular, empadronado, residente trabajando y con orden de expulsión)", Revista de Derecho migratorio y extranjería, $\mathrm{N}^{\circ} 1$ (2002), pp. 89-97, p. 89.

${ }^{6}$ Véase Anuario Estadístico Ministerio del Trabajo e Inmigración de España 2008.

7 El Partido Popular español sitúa la cifra de inmigrantes ilegales en un millón de personas. Los argumentos para tal resultado parten de la diferencia entre inmigrantes empadronados e inmigrantes con tarjeta de residencia. Por su parte, el Gobierno ha manifestado que no hay más de trescientas mil personas en esta situación en España. Fuente: Noticias Partido Popular. En http://www.pp.es (Visitado 8/04/10). Además, sirve de fuente la declaración de Jesús Caldera, Ministro del Trabajo y Asuntos Sociales. En Prensa, el 14 de febrero de 2008.

${ }^{8}$ Mediante oficio 151-358, el poder ejecutivo chileno, formuló con fecha 18 de agosto de 2010, indicaciones al proyecto de ley para modificar la Ley $\mathrm{N}^{\circ} 18.216$, sobre medidas alternativas a las penas privativas o restrictivas de libertad (Boletín $\mathrm{N}^{\circ}$ 5838-07). Un copia de la indicación puede verse en:

http://camaradediputados.cl/pley/pley_detalle.aspx?prmID $=6214 \& \mathrm{prmBL}=5838-07 . \quad$ (Consultado por última vez el 22/10/2010).
} 
Polít. crim. Vol. 6, No 11 (Julio 2011), Art. 4, pp. 106 - 141.

[http://www.politicacriminal.cl/Vol_06/n_11/Vol6N11A4.pdf]

En este trabajo se pretende analizar desde un prisma jurídico penal crítico esta eventual expulsión de extranjeros, cuya normativización se contempla en el artículo 35 del PLMMA, el cual establece lo siguiente:

"Si el condenado a una pena igual o inferior a cinco años de presidio o reclusión menor en su grado máximo fuere un extranjero que no residiere legalmente en el país, el juez podrá sustituir el cumplimiento de la pena privativa de la libertad por su expulsión del territorio nacional, salvo que el condenado acredite tener arraigo familiar o social, o que desarrolle permanentemente un trabajo remunerado, pudiendo solicitarse informe a Gendarmería de Chile, para efectos de la sustitución de la pena privativa de la libertad de conformidad con lo dispuesto en los artículos 1 y siguientes. Asimismo, previa solicitud del Ministerio Público, el juez podrá ordenar el cumplimiento de la pena privativa de libertad, si la naturaleza del delito o las circunstancias de comisión lo justificaren.

A esta audiencia, deberá ser citado el Ministerio del Interior, a objeto que se pronuncie sobre la conveniencia de la sustitución de la pena privativa de la libertad por la expulsión del territorio nacional. Si se ordenare la expulsión, deberá oficiarse al Departamento de Extranjería del Ministerio del Interior, para efectos de que lleve a cabo la implementación de esta medida, debiendo mantenerse bajo la custodia de Gendarmería de Chile en el tiempo que medie entre la dictación de la sentencia condenatoria y la expulsión definitiva del territorio de la República"

El análisis lo realizaremos a partir de lo que creemos que es la norma jurídica mentora del proyecto sobre expulsión de extranjeros en Chile, esto es, el artículo 89 del Código Penal español. ${ }^{9}$ Desde ese plano, pretendemos conocer el origen de esta institución, las razones político criminales que demandaron su génesis, su naturaleza jurídica, su contenido y efectos. Así, al exponer su estructura, estaremos en condiciones de criticar con cierto acierto, su lúgubre identidad jurídica, la deficiente finalidad perseguida y la infracción de derechos que genera. Todas ellas, darán cuenta que de recogerse por el legislador chileno la expulsión de extranjeros, nos enfrentemos a una nueva institucionalidad que afecte no sólo derechos del propio extranjero, sino de la víctima del delito y de la propia sociedad chilena en su conjunto.

\section{Evolución histórica de la expulsión de extranjeros en España}

Con la LO 7/1985, de 1 de julio, denominada Ley Orgánica de Derechos y Libertades de los Extranjeros en España, más conocida como "Ley de Extranjería" (en adelante, LEX), se comienza a regular la situación de extranjeros que comparecen ante tribunales españoles por delitos cometidos dentro de este territorio.

$\mathrm{Su}$ finalidad era favorecer un censo real de los extranjeros que vivían en España y además aplicar medidas que favorecieran la expulsión de los que se encontraban en situación irregular. ${ }^{10}$

\footnotetext{
${ }^{9}$ Por razones de tiempo y estructura de trabajo, limitaremos el análisis al estudio sólo del artículo 89 del Código Penal español y no al artículo 108 que sanciona la expulsión como sustitutivo de las medidas de seguridad.

${ }^{10}$ La expulsión regulada en el Código Penal español de 1995, en los artículos 89 y 108 , es entendida como tal desde la LO 7/1985. Con anterioridad existen otros cuerpos legales penales que acuñan esta terminología pero referida a otras finalidades. Por ejemplo, en el artículo 130 del Código Penal de 1928 se establece: "que la expulsión de extranjeros, decretada por los tribunales como medida de seguridad,
} 
SALINERO, Sebastián. “La expulsión de extranjeros en el derecho penal. Una realidad en España, una posibilidad en Chile”.

En lo que atañe específicamente a la expulsión, la LO 7/1985 instaura el modelo de sustitución del proceso penal y de la pena, por la expulsión del territorio español de los extranjeros no comunitarios.

Esta sustitución se podía presentar en dos escenarios posibles. En primer lugar, respecto del extranjero que en un proceso penal era "encartado" por delitos menos graves, es decir, aquellos castigados con una pena de seis años de prisión, según el Código Penal de la época, ya fuere por hechos cometidos con anterioridad al procedimiento de expulsión o con posterioridad al mismo. En segundo lugar, se permitía la sustitución de la pena a la cual eran condenados los extranjeros por sentencia firme, en caso de delito menos grave, por la expulsión del territorio español.

Sin perjuicio del Proyecto de Ley Orgánica del Código Penal 102/1992, de 23 de Septiembre, ${ }^{11}$ el primer Código Penal que recoge la expulsión de extranjeros, claro que con una marcada distancia de la reconocida en el actual cuerpo punitivo, fue el del año 1928, el cual, como se sabe, se insertaba en una etapa histórica y política -la de la dictadura de Primo de Rivera- muy distinta a la actual. Es precisamente en los artículos 99 y 130 del referido Código donde, ${ }^{12}$ por primera vez en la historia de España, aparece la institución de la expulsión de los extranjeros como consecuencia de la comisión de delitos. $^{13}$

Posteriormente, con la entrada en vigencia del Código Penal de 1995 se pone fin a cualquier crítica, por lo menos de carácter formal relativa a la expulsión, y se materializa esta consecuencia jurídica penal, específicamente en los artículos 89 y 108. El primero referido a la sustitución de una pena y el segundo a la sustitución de una medida de seguridad. Para la utilización de este sustituto penal se estaba $-\mathrm{y}$ se sigue estando- a la pena asignada al delito, sustituyéndose totalmente las que sean inferiores a seis años. También se permitía la sustitución por la expulsión tratándose de penas iguales o superiores a 6 años, sólo en el caso del último cuarto de la pena. Por otra parte, para la procedencia de la expulsión sustitutiva de una medida de seguridad se requería que estuviésemos en presencia de una medida de seguridad privativa de libertad. En ambos casos de sustitución -ya sea de la pena o de la medida de seguridadpor la expulsión, su procedencia estaba entregada de manera discrecional o facultativa al juez o tribunal.

será comunicada a las autoridades gubernativas del lugar en que el reo deje extinguida la condena que le haya sido impuesta, o del en que residiere, para que se lleve a efecto en el plazo que el Tribunal haya fijado para ello."

${ }^{11}$ Con este proyecto se introdujo por primera vez la expulsión del extranjero no residente legalmente en España, como alternativa a determinadas penas privativas de libertad, en su artículo 89.

12 El art. 99 señalaba: "los Tribunales, en sus sentencias, decretaran la expulsión de los extranjeros del territorio nacional, además de imponerles la pena correspondiente, en los mismos casos en que, si el delincuente fuese español, habrían de exigirle caución; y podrán asimismo, acordarla en los demás casos que estimen oportuno". A su vez, el art. 130 dispone: "la expulsión de los extranjeros, decretadas por los Tribunales como medida de seguridad, será comunicada las Autoridades gubernativas del lugar en que el reo deje extinguida la condena que le haya sido impuesta, o del en que residiera, para que se lleve a efecto en el plazo que el tribunal haya fijado para ello".

13 MUÑOZ LORENTE, José, "La expulsión del extranjero como medida sustitutiva de las penas privativas de libertad: el artículo 89 del CP tras su reforma por la ley orgánica 11/2003", Revista de Derecho Penal y Criminología, No Extra 2 (2004), pp. 401-482, p. 418. 
Tanto la expulsión, como alternativa a la pena, como la expulsión alternativa a una medida de seguridad, consagradas en la LO 10/1995, encuentran parte de su redacción original en la Ley de Extranjería de $1985^{14}$ y en la derogada Ley de Peligrosidad y Rehabilitación Social. ${ }^{15}$

Con el Código Penal español de 1995, se pone fin a la exclusiva regulación administrativa de la expulsión. Ahora esta institución tiene un desarrollo dual, tanto penal como administrativo. La primera ejercida por el Código Penal y la segunda por la LO 7/1985, sobre derechos y libertades de los extranjeros en España y su integración social. Todo, sin perjuicio que lo que realmente existió, fue el traslado sistemático de la expulsión de una legislación penal especial al Código Penal como principal texto punitivo. $^{16}$

La primera reforma del artículo 89, tras la vigencia del Código Penal de 1995, fue realizada a través de la Ley Orgánica 8/2000, de reforma a la Ley de Extranjería, que introdujo un número $4^{\circ}$ en el artículo 89 en el que se prohibía $-\mathrm{y}$ se sigue prohibiendola sustitución de la pena por la medida de expulsión respecto a determinados y concretos delitos relacionados con el tráfico ilegal de mano de obra y/o empleo de súbditos extranjeros, en los delitos contra los derechos de los extranjeros y en el favorecimiento o integración en asociaciones ilícitas dedicadas al tráfico ilegal de personas. Prohibición esta que, como señala Muñoz Lorente, tiene todo sentido de cara a evitar la continuidad delictiva que, casi con toda seguridad, se daría si la pena privativa de libertad se sustituyese por la expulsión del territorio nacional. Así, pensemos en los patrones de las denominadas "pateras" a quienes, tras ser condenadas, se les sustituyese la pena por la expulsión, la continuidad delictiva sería casi segura -al día siguiente de la expulsión podrían seguir patroneando nuevas "pateras"- y el efecto criminógeno respecto a otros sujetos seria claro, dado que se estaría enviando el mensaje de que la conducta de patronear "pateras" no es delictiva en España o, si lo es, no tiene ningún tipo de consecuencia penal salvo la de ser repatriado que, como se podrá comprender, no es percibido por tales sujetos como un mal. ${ }^{17}$

\footnotetext{
${ }^{14}$ El artículo 21.2 de la Ley de Extranjería española, rezaba: "Si el extranjero fuere condenado por delito menos grave y en sentencia firme, el juez o tribunal podrán acordar, previa audiencia de aquel, su expulsión del territorio nacional como substitutiva de las penas que le fueren aplicables, asegurando en todo caso la satisfacción de las responsabilidades civiles a que hubiere lugar, todo ello sin perjuicio de cumplir, si regresara a España, la pena que le fuere impuesta."

${ }^{15}$ La ley sobre peligrosidad y rehabilitación social fue una ley del Código Penal español aprobada por el régimen franquista el 5 de agosto de 1970 y derogada el 23 de noviembre de 1995. Sustituía principalmente a la Ley de vagos y maleantes para el control de todos los elementos considerados antisociales. Entre ellos se incluía a aquellos que practicaran la mendicidad, la homosexualidad, el vandalismo, el tráfico y consumo de drogas, la venta de pornografía, la prostitución y el proxenetismo. Así como a los inmigrantes ilegales y cualquiera que fuera considerado peligroso moral o socialmente por el régimen.

${ }^{16}$ Esta incorporación ha sido calificada de innecesaria por algunos autores, al considerar que tanto los supuestos del art. 89 y 108 del Código Penal ya estaban incluidos en la Ley de Extranjería. De esta opinión GARCÍA ALBERO, Ramón, en QUINTERO OLIVARES, Gonzalo (Dir.), Comentarios al nuevo Código Penal, Pamplona: Aranzadi, 1996, p. 547; Además, esta incorporación al principal texto punitivo ya constituía la intención del legislador desde el Proyecto de Ley Orgánica de Código Penal de 1980 al menos en lo que respecta a la expulsión como un sustituto a las medidas de seguridad.

${ }^{17}$ MUÑOZ LORENTE, "La expulsión del extranjero”, cit. nota n 13, p. 424.
} 
Luego, tras la reforma - no ajena de críticas $-^{18}$ efectuada por la Ley Orgánica 11/2003, de 29 de septiembre, ${ }^{19}$ sobre medidas concretas en materia de seguridad ciudadana, violencia doméstica e integración social de los extranjeros, ${ }^{20}$ los artículos 89 y 108 del Código Penal conminan al juez o tribunal a sustituir las penas privativas de libertad y medidas de seguridad impuestas a un extranjero no residente legalmente en España por su expulsión del territorio nacional. La reforma se encaminó principalmente a lograr que la expulsión constituya la regla y el cumplimiento efectivo de la pena o medida de seguridad su excepción. ${ }^{21}$ Este carácter mecánico que el legislador revistió a la expulsión, como veremos más adelante, fue matizado por la interpretación que del precepto hizo el Tribunal Supremo. ${ }^{22}$

\footnotetext{
${ }^{18}$ Una crítica severa puede verse en: SANZ MORÁN, Ángel, "Reflexión de urgencia sobre las últimas reformas de la legislación penal”, Revista de Derecho Penal, No 11 (2004), pp. 11-40, p. 12 y 39. Considera que esta ley, junto a otras, representan una preocupante involución en relación al moderno derecho penal, caracterizado por su rasgo humanitario y liberal. Además, estima que es derecho penal simbólico en el sentido más negativo; En el mismo sentido, NAVARRO CARDOSO, Fernando, "Expulsión "penal" de extranjeros: una simbiosis de derecho penal "simbólico" y derecho penal del "enemigo"”, Revista de Derecho Penal y Criminología, No 17 (2006), pp. 153-182, p.179 y ss.; LAURENZO COPELLO, Patricia, "Ultimas reformas en el derecho penal de extranjeros: Un nuevo paso a la política de exclusión", Revista Jueces para la Democracia, No 50 (2004), pp. 30-35, pp. 1 y ss.; RODRÍGUEZ MESA, Ma. José, "El sistema penal ante el reto de la inmigración clandestina. Funciones instrumentales y simbólicas”, en PÉREZ ÁLVAREZ, Fernando, (Ed.), Serta in Memoriam Alexandri Baratta, Universidad de Salamanca, Salamanca, 2004, pp. 845-869, p. 849. Entiende un trato desigual que contribuye a la marginación y exclusión social; En un sentido similar, TERRADILLOS BASOCO, Juan. "Sistema Penal e Inmigración", en PÉREZ ÁlVAREZ, Fernando, (Ed.), Serta in Memoriam Alexandri Baratta, Universidad de Salamanca, Salamanca, 2004, pp. 1463-1481, p. 1468; RÍOS CORBACHO, José Manuel, "Regulación jurídica de la extranjería: situación actual”, en RUÍZ RODRÍGUEZ, Luis Ramón (Coord.), Sistema penal y exclusión de extranjeros, Albacete: Bomarzo, 2006, pp. 67-103, p. 69. Señala que el fenómeno de la inmigración se ha caracterizado en España por su rapidez e intensidad a la hora de obligar al Gobierno a desarrollar y modificar, hasta tres veces, en un período de cuatro años, la ley que regula la inmigración, los derechos y los deberes de los inmigrantes; También, algunos acercan ésta legislación al denominado derecho penal del enemigo, entre otros, PORTILLA CONTRERAS, Guillermo, El derecho penal entre el cosmopolitismo universalista y el relativismo posmodernista, Valencia: Tirant, 2007, p. 147 y ss.; DE LUCAS, Javier, "Nuevas Estrategias de Estigmatización. El derecho frente a los inmigrantes", en PORTILLA CONTRERAS, Guillermo (Coord.), Mutaciones del Leviatán. Legitimación de los nuevos modelos penales, Madrid: Akal, 2005, pp. 213 y ss.; Por último, considera funcionalmente correcto ésta regulación desde la perspectiva del denominado Derecho penal del enemigo, CANCIO MELIÁ, Manuel; MARAVER GÓMEZ, Mario, "El derecho penal español ante la inmigración: Un estudio político criminal", en BACIGALUPO, Silvina; CANCIO MELIÁ, Manuel (Coord.), Derecho Penal y Politica Transnacional, Barcelona: Atelier, 2005, pp. 343-415, p. 346.

${ }^{19}$ Conforme a la Exposición de motivos de la LO 11/2003, explícita los objetivos de la reforma del art. 89 CP: "se trata de evitar que la pena y su cumplimiento se conviertan en forma de permanencia en España quebrantando así de manera radical el sentido del ordenamiento jurídico en su conjunto. Para ello la reforma pretender dar adecuado cause a que el juez penal acuerde la sustitución de la pena impuesta al extranjero no residente legalmente en España que ha cometido un delito, por su expulsión.”.

${ }^{20}$ Título de esta ley que adolece de un eufemismo sin parangón. Esta modificación legal no busca la integración de los extranjeros, sino todo lo contrario, la de aumentar la exclusión al punto de convertir la expulsión en regla general y no en la excepción como venia siendo. Pasa de ser una sustitución facultativa a obligatoria para el Juez o el Tribunal respectivo; De esta misma opinión puede verse a MUÑOZ LORENTE, "La expulsión del extranjero", cit. nota no 13, p. 404.

${ }^{21}$ Un notable paralelo entre el carácter facultativo y obligatorio de la expulsión, a raíz de la reforma introducida por LO 11/2003, puede verse en BRANDARIZ GARCÍA, José Ángel, Política Criminal de la Exclusión. El Sistema Penal en Tiempos de Declive del Estado Social y de Crisis del Estado-Nación, Granada: Comares, 2007, p. 120.

${ }^{22}$ Véase STS 901/2004, de 8 de julio.
} 
Polít. crim. Vol. 6, No 11 (Julio 2011), Art. 4, pp. 106 - 141.

[http://www.politicacriminal.cl/Vol_06/n_11/Vol6N11A4.pdf]

Por último, mediante reforma de LO 5/2010, de 22 de junio, se modificó el Código Penal español. ${ }^{23}$ Dentro del masivo cúmulo de modificaciones e incorporación de nuevas instituciones al ordenamiento jurídico penal español, la norma del artículo 89 sufre severos cambios.

El nuevo texto legal quedó redactado de la siguiente manera:

"1. Las penas privativas de libertad inferiores a seis años impuestas a un extranjero no residente legalmente en España serán sustituidas en la sentencia por su expulsión del territorio español, salvo que el Juez o Tribunal, previa audiencia del penado, del Ministerio Fiscal y de las partes personadas, de forma motivada, aprecie razones que justifiquen el cumplimiento de la condena en un centro penitenciario en España.

También podrá acordarse la expulsión en auto motivado posterior, previa audiencia del penado, del Ministerio Fiscal y de las demás partes personadas.

2. El extranjero no podrá regresar a España en un plazo de cinco a diez años, contados desde la fecha de su expulsión, atendidas la duración de la pena sustituida y las circunstancias personales del penado.

3. La expulsión llevará consigo el archivo de cualquier procedimiento administrativo que tuviera por objeto la autorización para residir o trabajar en España.

4. Si el extranjero expulsado regresara a España antes de transcurrir el periodo de tiempo establecido judicialmente, cumplirá las penas que fueron sustituidas. No obstante, si fuera sorprendido en la frontera, será expulsado directamente por la autoridad gubernativa, empezando a computarse de nuevo el plazo de prohibición de entrada en su integridad.

5. Los jueces o tribunales, a instancia del Ministerio Fiscal y previa audiencia del penado y de las partes personadas, acordarán en sentencia, o durante su ejecución, la expulsión del territorio nacional del extranjero no residente legalmente en España, que hubiera de cumplir o estuviera cumpliendo cualquier pena privativa de libertad, para el caso de que hubiera accedido al tercer grado penitenciario o cumplido las tres cuartas partes de la condena, salvo que previa audiencia del Ministerio Fiscal y de forma motivada aprecien razones que justifiquen el cumplimiento en España.

6. Cuando, al acordarse la expulsión en cualquiera de los supuestos previstos en este artículo, el extranjero no se encuentre o no quede efectivamente privado de libertad en ejecución de la pena impuesta, el Juez o Tribunal podrá acordar, con el fin de asegurar la expulsión, su ingreso en un centro de internamiento de extranjeros, en los términos y con los límites y garantías previstos en la Ley para la expulsión gubernativa.

En todo caso, si acordada la sustitución de la pena privativa de libertad por la expulsión, ésta no pudiera llevarse a efecto, se procederá a la ejecución de la pena originariamente impuesta o del periodo de condena pendiente, o a la aplicación, en su caso, de la suspensión de la ejecución de la misma o su sustitución en los términos del artículo 88 de este Código.

7. Las disposiciones establecidas en los apartados anteriores no serán de aplicación a los extranjeros que hubieran sido condenados por la comisión de delitos a que se refieren los artículos 312, 313 y 318 bis de este Código."

El objetivo de esta modificación no es explicado en la exposición de motivos de la Ley. Empero, a nuestro juicio, la expulsión es revitalizada de manera de endurecer sus

\footnotetext{
${ }^{23}$ Véase Boletín Oficial de las Cortes Generales el 23 de junio de 2010.
} 
SALINERO, Sebastián. "La expulsión de extranjeros en el derecho penal. Una realidad en España, una posibilidad en Chile”.

consecuencias, ampliar los supuestos de su procedencia y regular situaciones problemáticas que se daban en el foro de los tribunales, donde existían interpretaciones diversas y en la mayoría de los casos se resolvía con un criterio "Pro-extranjero", de esta manera la expulsión pasaba de ser la regla general automática a la excepción.

En definitiva, con esta modificación se busca que la expulsión como consecuencia jurídica no caiga en el desuso generalizado que tiñó a los tribunales españoles en el lustro anterior.

\section{La expulsión de extranjeros en Chile}

En Chile, lo que dice relación con extranjería se encuentra regulado en el Decreto Ley $\mathrm{N}^{\mathrm{o}} 1094$ de 1975, también denominado Ley de Extranjería (en adelante, LECH), Decreto Supremo No 597 de 1984, sobre Reglamento de Extranjería y Decreto Supremo $\mathrm{N}^{\mathrm{o}} 5.142$ de 1960 (en adelante, RLECH), el que reúne disposiciones sobre nacionalización de extranjeros.

Las exigencias, condiciones y prohibiciones que establece la legislación son numerosas y de variada índole. En primer lugar se encuentran todos aquellos extranjeros que ingresen al país no obstante afectarles alguna de las prohibiciones que establece el Reglamento de Extranjería para el ingreso; o aquellos que después de haber ingresado al país incurren en fomentar doctrinas o realizan actividades contrarias al régimen democrático, atentan contra la seguridad exterior, seguridad interior u orden público o se dedican al tráfico de drogas, contrabando o trata de blancas. A todas estas personas, así como a quienes falsifiquen su documentación, se les rechazarán las solicitudes de visa o de prórroga de visa y deberán abandonar el país o ser expulsados conforme al procedimiento de expulsión.

Asimilado esto, debemos indicar que la expulsión de extranjeros sin residencia legal en el país, desde la perspectiva penal, no sería del todo novedosa en la legislación chilena. Efectivamente, la LECH contempla una serie de disposiciones que a nuestro juicio tienen naturaleza penal, pues, existe una descripción típica sancionada con una pena. Así, esta legislación que en general es de naturaleza administrativa, contempla en su articulado la sanción de expulsión que se aplicaría en los siguientes casos: a) A los extranjeros que ingresen al país o intenten egresar de él, valiéndose de documentos falsificados, adulterados o expedidos a nombre de otra persona o hagan uso de ellos durante su residencia. Estos serán sancionados con pena de prisión de 3 años y 1 día a 5 años, debiendo disponerse, además, su expulsión, la que se llevará a efecto tan pronto el afectado cumpla la pena impuesta. En estos delitos no procede la remisión condicional de la pena ${ }^{24}$ b) Asimismo, se sanciona a los extranjeros que ingresen al país o intenten egresar de él clandestinamente, con la pena de prisión de 3 años y 1 día a 5 años. Si lo hicieren por lugares no habilitados, la pena será de prisión desde 61 días a 5 años y si entraren al país existiendo a su respecto causa de impedimento o prohibición de ingreso, serán sancionados con la pena de prisión de 3 años y 1 día a 10 años. Una vez cumplida la pena impuesta en los casos precedentemente señalados, los extranjeros serán expulsados del territorio nacional: ${ }^{25}$ c) También son sancionados los extranjeros que continuaren residiendo en el país después de haberse vencido sus plazos de residencia

\footnotetext{
${ }^{24}$ Véase art. 68 LECH.

${ }^{25}$ Véase art. 69 LECH.
} 
legal o los extranjeros que durante su permanencia en el país no dieren cumplimiento oportuno a la obligación de empadronarse, de obtener documento de identidad, de comunicar a la autoridad cuando corresponda, el cambio de domicilio o actividades, con multa, sin perjuicio de que pueda disponerse su abandono obligado del país o su expulsión. ${ }^{26}$

La medida de expulsión de los extranjeros debe ser dispuesta por Decreto Supremo fundado, suscrito por el Ministro del Interior. No obstante, tratándose de los extranjeros que sean titulares de permiso de turismo o prolonguen su permanencia con dicho permiso vencido, la expulsión es dispuesta por resolución del Intendente Regional respectivo. $^{27}$

La expulsión se ejecuta materialmente conforme al Decreto Supremo No 597 de 1984, sobre Reglamento de Extranjería, donde se debe transcribir la orden de expulsión a la Policía de Investigaciones de Chile para su ejecución y deber ser notificada por escrito y personalmente al afectado, por la misma autoridad policial. El extranjero afectado con una medida de expulsión, durante el acto de notificación, podrá manifestar su intención de recurrir en contra de la medida o conformarse con ella. ${ }^{28}$

Lo interesante de esta normativa radica, a nuestro entender, en dos puntos: el primero, que no obstante ser una legislación administrativa, a lo menos desde la perspectiva orgánica, contempla infracciones penales, las cuales deben ser sustanciadas y juzgadas en sede criminal; y en segundo término, se privilegia un criterio de prevención general, al exigirse el cumplimiento de la pena impuesta para la infracción respectiva, debiendo luego, ejecutarse la expulsión que es resorte privativo de la administración.

Sin perjuicio de lo anterior, los supuestos de expulsión del legislador chileno se refieren, en general, a infracciones sobre ingreso, salida y permanencia de extranjeros en Chile. Su existencia y fines son absolutamente distintos a la que se pretenden en el PLMMA, los que tienen un carácter inminentemente administrativo que busca el control de los flujos migratorios desde y hacia Chile.

Para terminar este capítulo, es necesario hacer presente un hecho de indudable relevancia: el PLMMA en lo que se refiere a la expulsión, la concibe como un instrumento discrecional y no obligatorio para el juzgador. El artículo 35 utiliza la voz "podrá", con lo que se quiere especificar que la expulsión no opera como un sustitutivo obligatorio para el juez o tribunal, sino que éstos, en un análisis de las concretas circunstancias del caso y la persona del extranjero, decidirán o no sobre la procedencia de la expulsión. Es a lo mejor en este punto, en donde a pesar de la gran similitud entre la norma española y el proyecto chileno, se marca una diferencia importante entre ambas normas jurídico penales.

\section{El modelo español como fuente para el proyecto de expulsión en Chile}

Como se podrá advertir y como revisaremos en los títulos siguientes, no sólo existen claras semejanzas semánticas entre el artículo 89 del Código Penal español (en adelante

\footnotetext{
${ }^{26}$ Véase arts. 71 y 72 LECH.

${ }^{27}$ Véase art. 84 LECH.

${ }^{28}$ Véase art. 173 RLECH.
} 
SALINERO, Sebastián. “La expulsión de extranjeros en el derecho penal. Una realidad en España, una posibilidad en Chile".

CPe) y el pretendido artículo 35 de la PLMMA, sino también existe un innegable parecido en la estructura jurídica de ambas normas: a) sustitución total de una pena: penas iguales o inferiores a 5 años de presidio o reclusión menor en su grado máximo para el caso chileno y penas iguales o inferiores a 6 años para el caso español; b) sujeto objeto de la expulsión: extranjero sin residencia legal; c) fundamento para la negativa de la expulsión: residencia legal en Chile o España; d) legitimación activa: con ciertos matices, Ministerio Fiscal en España y Ministerio Público en Chile; e) formalidad procesal de una audiencia para la procedencia de la expulsión: con la comparecencia de las partes en el proceso en España y del Ministerio del Interior en Chile, y; f) ejecución de la pena privativa de libertad: si la naturaleza del delito o las circunstancias de comisión lo justifican en el caso chileno y razones justificadas en el caso español.

Lo anterior, hace que existan claros antecedentes que la norma española sirvió de modelo para esta incipiente proposición de ley, y por último, se puede agregar como fundamento que justificaría la norma española como modelo del proyecto chileno, el hecho que históricamente hemos recurrido al legislador español como fuente para nuestro Derecho penal. En efecto, aunque sea una obviedad recordarlo, la base del Proyecto de nuestro Código Penal de 1874 fue el Código Penal Español de 1848/1850. Secundariamente se tuvo también en vista el Código belga de 1867, recomendado por el Ministro de Justicia. La otra gran fuente de inspiración para la doctrina penal chilena ha sido la origen germánico, no obstante para el caso particular de la propuesta legislativa, el recurso a esta fuente debe ser negado, dado que si bien se contempla la expulsión de extranjeros en el ordenamiento alemán, esta tiene otra estructura y características que la separan del proyecto legal chileno y la acercan al denominado Derecho Administrativo sancionador.

\section{Política criminal y expulsión}

Las razones político criminales en las cuales se asienta la expulsión en el ordenamiento español son de variada índole. Incluso algunos estiman que se encuentran ocultas, y las razones que se dan en el texto expreso de la ley son insuficientes para entender el verdadero significado de la expulsión. ${ }^{29}$

En efecto, la LO 11/2003 en su exposición de motivos aduce como razón, la necesidad de evitar que la pena y su cumplimiento se conviertan en formas de permanencia en España quebrantando así de manera radical el sentido del ordenamiento jurídico en su conjunto. $^{30}$ Correspondería aparentemente a una política criminal vinculada a una política de extranjería, que persigue controlar los flujos migratorios hacia España. Así, de cierto modo el legislador está motivado por razones de prevención general. Sin embargo, como indica Miró Llinares, la argumentación del legislador no se sostiene porque siempre queda a salvo, luego del cumplimiento de la pena por parte del extranjero, la aplicación de la medida administrativa de expulsión. ${ }^{31}$ Por otra parte, esta

\footnotetext{
${ }^{29}$ CANCIO MELIÁ; MARAVER GÓMEZ, “El derecho penal español”, cit. nota nº 18, p. 383.

30 Véase LO 11/2003, Exposición de motivos, apartado 4; Cfr. CANCIO MELIÁ; MARAVER GÓMEZ, "El derecho penal español”, cit. nota n 18, p. 385.

${ }^{31}$ MIRÓ LLINARES, Fernando. "Política comunitaria de inmigración y Política criminal en España. ¿Protección o "exclusión” penal del inmigrante”, RECPC, 10-05 (2008), pp. 1-31, p. 22. En http://criminet.ugr.es/recpc/10/recpc10-05.pdf (Consultado el 10/10/2010); RODRÏGUEZ CANDELA, José Luis. "La expulsión del extranjero en el nuevo Código Penal", Revista Jueces para la Democracia, No 33 (1998), pp. 59-70, p. 59 y ss.
} 
afirmación también carece de sustento empírico que confirme que efectivamente existe el fenómeno de la comisión de delitos con la finalidad de permanecer en territorio español. ${ }^{32}$

Por otro lado, un sector doctrinal ha señalado que la expulsión descansa en la dificultad de reinserción social por falta de arraigo que tienen los inmigrantes irregulares en el evento de cumplir penas en España. Al respecto, como correctamente enfatizan Cancio Meliá y Maraver Gómez, esta afirmación no se encuentra demostrada y no puede servir para justificar la exclusión absoluta del inmigrante de los fines constitucionales de reeducación y reinserción de las penas, ${ }^{33}$ sin perjuicio de que, las posibilidades de reinserción dependerán de las circunstancias de cada sujeto en particular. ${ }^{34}$

Otro sector doctrinal afirma la conveniencia de la medida en orden a controlar la calidad del inmigrante. ${ }^{35}$ Además de poco afortunado este postulado por atentar contra la dignidad de las personas y a la igualdad de las mismas, no merece mayor análisis.

También se ha señalado que la razón fundamental de esta medida obedece a la necesidad de desmasificar las cárceles y reducir los costes económicos asociado a ello. ${ }^{36}$ Situación que en el parecer de Giménez-Salinas no es cierta, por el escaso impacto de la población extranjera en las prisiones españolas. ${ }^{37}$ Tesis que también carece de evidencia empírica. ${ }^{38}$

Sin embargo, es bastante probable que esta última causa pueda ser la ratio legis de los artículos 89 y 108 del Código Penal español. Empero, como sucede asiduamente, no sabemos cuál es el respaldo científico con que cuenta esta afirmación. Si bien el colectivo de extranjeros en los últimos diez años ha incrementado la población penitenciaria española, la duda está en saber, qué porcentaje de aquellos son extranjeros no residentes legalmente en España y de qué modo éstos inciden en los costes y en el sistema penitenciario.

Para el caso chileno, el prelegislador no realiza una exposición de motivos o una declaración que permita establecer la finalidad de esta institucionalidad. Tampoco

\footnotetext{
${ }^{32}$ CANCIO MELIÁ; MARAVER GÓMEZ, "El derecho penal español”, cit. nota n 18, p. 386.

33 CANCIO MELIÁ; MARAVER GÓMEZ, "El derecho penal español”, cit. nota no 18, pp. 390 y ss.; MIRO LLINARES, "Política comunitaria de inmigración”, cit. nota n 31, p. 23.

34 Cfr. ASUA BATARRITA, Adela. "La expulsión del extranjero como alternativa a la pena: incongruencias de la subordinación del Derecho penal a las políticas de la inmigración”, en LAURENZO COPELLO, Patricia (Coord.), Inmigración y Derecho penal: Bases para un debate, Valencia: Tirant, 2002, p. 57.

${ }^{35}$ LUZÓN CUESTA, J.M., citado por ASÚA BATARRITA, "La expulsión del extranjero", cit. nota n 20, p. 57, nota 34; En el mismo sentido, pero sin considerar la conveniencia MAPELLI CAFFARENA, Borja, Las consecuencias jurídicas del delito, $4^{\circ}$ Ed., Madrid: Civitas, 2005, p. 127.

36 GRACIA MARTÍN/ALASTUEY DOBON, en GRACIA MARTÍN (coord.), Lecciones de consecuencias jurídicas del delito, Valencia: Tirant, $3^{\circ}$ Ed., 2004, p. 323; ASÚA BATARRITA, "La expulsión del extranjero", cit. nota $n^{\circ} 34$, p. 55; FLORES MENDOZA, Fátima, "La expulsión del extranjero en el Código Penal español", en LAURENZO COPELLO, Patricia (Coord.), Inmigración y Derecho penal: Bases para un debate, Valencia: Tirant, 2002, p. 108; MAPELLI CAFFARENA, Las consecuencias jurídicas del delito, cit. nota $\mathrm{n}^{\circ} 35$, p. 127; Esta afirmación, también, se encuentra reconocida en la exposición de motivos de la LO 11/2003.

37 GIMÉNEZ-SALINAS, Esther. "Extranjeros en prisión”, Cuadernos del Instituto Vasco de Criminología, No 7 Ex. (1994), pp. 133-146, p. 139.

${ }^{38}$ CANCIO MELIA; MARAVER GÓMEZ, "El derecho penal español”, cit. nota nº 18, pp. 386 y ss.
} 
SALINERO, Sebastián. "La expulsión de extranjeros en el derecho penal. Una realidad en España, una posibilidad en Chile".

hemos escuchado en el seno del foro del ejecutivo o parlamentario a qué obedece esta nueva manifestación. Más dudas quedan aún, del por qué la expulsión es tratada a propósito de una ley que plantea -o modifica- medidas alternativas a las penas privativas o restrictivas de libertad, salvo que obedezca a la intención de calificarla jurídicamente como tales, lo que desde ya, rechazamos por razones de prevención especial que es la principal característica de esta medidas, las cuales persiguen evitar los efectos nocivos de las penas privativas de libertad, favoreciendo la resocialización y rehabilitación del penado, ${ }^{39}$ finalidad que son muy distantes de concretizarse con la expulsión.

Es altamente probable que la expulsión obedezca a la necesidad de desmasificar las cárceles. Afirmación que es absolutamente especulativa y no tenemos cómo corroborar. Pero si podemos decir, que si así fuese, la prevalencia de los presos extranjeros en las cárceles chilenas es marginal. Según el Compendio Estadístico de Gendarmería de Chile, correspondiente al año 2008, ascendían a 1945 personas, ${ }^{40}$ de los cuales, sólo 1.283 se encuentran condenados -técnicamente habilitados para que sus condenas sean sustituidas por la expulsión- y cumpliendo una pena privativa en un recinto penitenciario. En este estado de cosas, tenemos como resultados que la prevalencia de extranjeros en cárceles chilenas es de un $3,9 \%,{ }^{41}$ y sólo el $2,6 \%$ podría ser susceptibles de expulsión. Por otro lado, entendiendo que la sobrepoblación o hacinamiento en las cárceles chilenas es cercano al $160 \%,{ }^{42}$ el impacto de la medida en torno a liberar plazas en las prisiones, también sería bajo o reducido.

Además de este motivo, también podríamos argüir como consecuencia de la anterior, la necesidad de reducir los índices de prisionización que hoy nos sitúa como el país más encarcelador de Sudamérica, con una tasa de 305 personas presas por cada 100.000 habitantes. ${ }^{43}$ El proyecto así lo indica, manifestando la preocupación del gobierno en torno a esta temática. ${ }^{44}$

\footnotetext{
${ }^{39}$ Cfr. CURY URZUA, Enrique, Derecho penal. Parte General. Santiago: Universidad Católica de Chile, 8 ad., 2005, p. 729; A propósito de la Remisión Condicional de la Pena, NOVOA MONREAL, Eduardo, Curso de Derecho penal Chileno. Parte General. Tomo II. Santiago: Editorial Jurídica de Chile, $3^{\mathrm{a}}$ Ed., 2010, pp. 324 y ss.; ETCHEBERRY, Alfredo, Derecho penal. Parte General. T. II. Santiago: Editorial

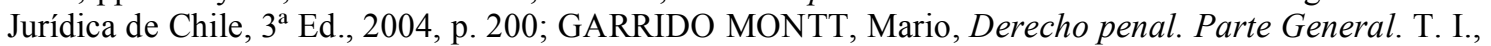

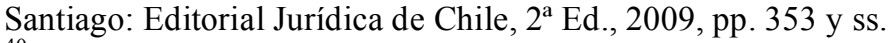

${ }^{40}$ Véase Compendio Estadístico de Gendarmería de Chile 2008. El total de 1945 comprende tanto: condenados, imputados, detenidos y procesados del antiguo sistema.

${ }^{41}$ La población penal para el año 2008 es de 49.359 personas. Fuente: Ministerio del Interior de Chile (División Seguridad Pública).

${ }^{42}$ El porcentaje de sobrepoblación penal crece de 145,2\% el año 2007 a 160,6 en Marzo de 2010. Fuente: Balance de Delincuencia 2009. Fundación Paz Ciudadana.

${ }^{43}$ Véase Balance de la Fundación Paz Ciudadana 2010. Según esta Fundación, Chile ocuparía el tercer lugar en América del Sur, tras Guayana Francesa y Surinam. No obstante, estos países se encuentran por debajo de nuestra tasa de población penal: Para el caso de Surinam, la tasa se estableció en el año 2005 y no corresponde al mismo año en que se determino para Chile. Además, según Human Rights Report, esta nación a fines del año 2008 tenía un universo penitenciario de 915 personas, lo cual refleja que su tasa real penitenciaria es de 146 y no de 356 como se informa. Respecto de Guayana Francesa, no es producible un análisis comparativo, al no ser un país, sino que es territorio francés de ultramar. Si no se entiende así, podríamos comparar regiones y arribar a la absurda conclusión de que la Región de Atacama -población similar a la Guayana- tiene una tasa de población penal inmensamente superior a la Guayana en cuestión. En definitiva, Chile es el país más encarcelador de toda América del Sur.

44 Véase Indicaciones a la indicación sustitutiva al proyecto de ley tendiente a modificar la Ley $\mathrm{N}^{\mathrm{o}}$ 18.216 , p. 2.
} 
Polít. crim. Vol. 6, No 11 (Julio 2011), Art. 4, pp. 106 - 141.

[http://www.politicacriminal.cl/Vol_06/n_11/Vol6N11A4.pdf]

Con estos resultados anteriores, podemos concluir que la incidencia de los extranjeros en las prisiones chilenas es marginal, de manera que, poco y nada variaría la tasa de población penal con el hecho de entrar en operaciones el instituto de la expulsión de ciudadanos extranjeros. ${ }^{45}$

También, siguiendo el caso español, se podría pensar que la expulsión obedece a una política criminal vinculada a una política de extranjería que persigue controlar los flujos migratorios hacia Chile. Pero esta afirmación no se sustenta por si sola, al ser tan menor el número de inmigrantes asentados en Chile y al ser manifiesto que el prelegislador penal con el PLMMA no está recogiendo necesidades administrativas de la ley y reglamento de extranjería. No se ocupa de regular la entrada, salida y permanencia de extranjeros en Chile, finalidad propia de este ordenamiento jurídico administrativo.

Por último, y a modo de conclusión parcial, creemos que desde una óptica teleológica, esta pretendida nueva institucionalidad de la expulsión carece de una finalidad que tenga por objeto hacerse cargo de un real problema no resuelto por el legislador penal. Los posibles fines que hemos identificado y que la pudiesen justificar, no son suficientes para consentir su creación, más allá de un irreflexivo propósito. En este entendido, la expulsión viene a coartar el carácter de último recurso del derecho penal, ${ }^{46}$ para dar una ilusa solución a la administración penitenciaria, o, como reacción protectora de otros intereses no precisados y que no tendrían la relevancia jurídica de los bienes tutelados por el legislador penal.

\section{Análisis jurídico penal de la expulsión de extranjeros. Revisión paralela.}

En el Código Penal español de 1995, recientemente reformado por LO 5/2010, la expulsión se encuentra recogida sistemáticamente en los artículos 89 y 108 . El primero, a propósito de la sustitución de una pena privativa de libertad y, el segundo, relativo a la sustitución de las medidas de seguridad. En ambos casos, el requisito subjetivo sine qua non, es que el sujeto activo de la conducta sea un extranjero que no resida legalmente en España.

Asimismo, en Chile el PLMMA recoge la expulsión de extranjeros del territorio nacional en su artículo 35, Capítulo V, Párrafo III, bajo el título "De la regla especial aplicable a los extranjeros". El proyecto de ley sólo regula la sustitución de una pena privativa de libertad y no de una medida de seguridad. También, se exige el requisito subjetivo de que el extranjero condenado no tenga residencia legal en Chile.

En los epígrafes siguientes, analizaremos la naturaleza jurídica de la expulsión, el ámbito de aplicación y los requisitos objetivos y subjetivos de estos mal llamados sustitutivos penales.

\footnotetext{
45 Según cálculos propios, pasaríamos de tener una tasa de 305 personas por cada 100.000 habitantes, a 297,4 de la misma escala. Con esta cifra, Chile continuaría siendo primero en el concierto continental.

${ }^{46}$ POLITOFF, Sergio, MATUS, Jean Pierre, RAMIREZ, María Cecilia, Lecciones de derecho penal chileno. Parte General. Santiago: Editorial Jurídica de Chile, 2a Ed., 2006, p. 67; CURY, Derecho, cit. nota ${ }^{\circ} 39$, p. 86.
} 
SALINERO, Sebastián. "La expulsión de extranjeros en el derecho penal. Una realidad en España, una posibilidad en Chile".

\subsection{Naturaleza jurídica}

La controversia en la doctrina española en torno a la naturaleza jurídica de la expulsión es ardua y con diversas posiciones bien fundamentadas.

Anticipando nuestra posición particular, pensamos que las figuras sobre la expulsión reguladas en el artículo 89 del $\mathrm{CPe}$-expulsión sustitutiva de una pena-como la referida en el artículo 108 del CPe -expulsión sustitutiva de una medida de seguridad- y la pretendida en Chile en el artículo 35 del PLMMA, responden a una misma y única naturaleza jurídica.

En la doctrina penal se discute si estamos en presencia de una pena, de una medida de seguridad, de un sustitutivo penal, de una condición suspensiva o de una medida administrativa.

Al respecto, algunos sostienen que estamos en presencia de una pena, señalando que la pena no es la expulsión sino la prohibición de regresar al país por un determinado lapso de tiempo. Para esta corriente la expulsión es el medio de ejecución de la verdadera pena: la privación del derecho a residir en determinados lugares o acudir a ellos. ${ }^{47}$

Existe casi unanimidad en la doctrina española en que la expulsión no puede ser una pena. ${ }^{48}$ Los argumentos para sustentar esta afirmación son, entre otros, que no figura en el catálogo de penas graves, menos graves y leves del artículo 33 del CPe. ${ }^{49}$ Para el caso chileno, también llegaríamos a la misma conclusión, dado que el propio proyecto no obstante erigirse como "Penas sustitutivas" no califica la expulsión como una pena, sino como una "regla especial". Incluso, estimando que la omisión en calificarse como pena, se debe a un olvido $u$ otro defecto técnico legislativo, igualmente, llegaríamos a la misma conclusión de no considerarla una pena por no cumplir los fines propios de éstas.

\footnotetext{
${ }^{47}$ De esta opinión, IZQUIERDO ESCUDERO, Francisco Javier, "Naturaleza jurídica de la sustitución prevista en el artículo 89 del Código Penal: comentario al auto del Tribunal Constitucional 106/1997 de 17 de abril", La Ley: Revista jurídica española de doctrina, jurisprudencia y bibliografía, $\mathrm{N}^{\circ} 5$ (1997), pp. 1861-1865, p.1862, quien ofrece dos argumentos: en primer lugar señala que aunque en el catálogo de penas del articulo $33 \mathrm{CP}$ no se encuentre la expulsión, si se encuentra la prohibición de acudir a España en un plazo de tiempo (art. 33.1 letra g); el segundo argumento lo extrae del proyecto de código penal de 1992, cuyo artículo 89 se remitía al articulo 451, que decía así: "El extranjero que quebrantare una decisión judicial de expulsión con prohibición expresa de regresar al territorio español será castigado con la pena de seis meses a dos años", de esto deduce Izquierdo Escudero que la prohibición de regresar a España por un tiempo determinado es una verdadera pena; En contra de este argumento se presenta RODRÍGUEZ CANDELA, José Luis, "La expulsión del extranjero en el nuevo Código Penal”, Revista Jueces para la Democracia, No 33 (1998), pp. 59-70, p. 60, al señalar "Tal tesis estimo es contraria al principio de legalidad de las penas recogido en el art. 2.1 del CP. Además, en relación a otros sustitutivos penales, los del artículo 88, continuamente el Código penal al referirse a ellos los califica de penas sustitutivas, sin que en el artículo 89, al referirse a la expulsión y prohibición de entrada, haga lo mismo"; Otros, estiman que la expulsión es una pena con una clara finalidad preventivo-especial negativa o incapacitadora - la persona a quién se expulsa queda incapacitada para cometer delitos en España- que, además tiene unos costes económicos muy reducidos. MONCLÚS MASÓ, Marta, "Hacia una política criminal diferenciada para los extranjeros: la consolidación de la expulsión como sanción penal especial", en RIVERA BEIRAS, Iñaki (Coord.), Política criminal y sistema penal: viejas y nuevas racionalidades punitivas, Barcelona: Anthropos, 2005, pp. 330-347, p. 347.

${ }_{48}$ Algún autor estima que la expulsión podría estar comprendida dentro de la pena de "Privación de derecho a residir en determinados lugares o acudir a ellos", que podría ser una pena grave, menos grave o leve en consideración a la duración de la misma IZQUIERDO ESCUDERO, "Naturaleza jurídica", cit. nota $\mathrm{n}^{\mathrm{o}} 47$, p. 1862.

${ }^{49}$ Véase art. $33 \mathrm{CP}$.
} 
En efecto, la expulsión no cumple con los fines de retribución, de prevención general y especial que son consustanciales a toda pena.

Desde el prisma del retribucionismo, donde la pena es entendida como un mal con el que merecidamente se retribuye, equilibra y expía la culpabilidad del autor por el hecho cometido, ${ }^{50}$ la expulsión no puede ser comprendida en todos los casos en que se aplique como una pena o castigo impuesto al sujeto que contraviene el ordenamiento jurídico penal. Existen ciertos aspectos particulares, derivados de la naturaleza del delito, de las concretas circunstancias del penado extranjero y la situación económica y social del país al cual pertenece, en la que la expulsión no puede ser considerada una sanción, sino más bien un beneficio o un premio. No es lo mismo, y por tanto no puede ser ponderado de manera equivalente, el extranjero que con sobrados recursos económicos llega a España o a Chile a realizar actos o negocios ilícitos, por sobre la persona que emigra por carecer de trabajo en su país de origen o del extranjero que huye por guerra o desorden social. Seguramente para el primero, la expulsión será un premio, y para el segundo la expulsión revestirá una real aflictividad sin parangón.

Estimamos, además, que la expulsión no cumple con los fines preventivos generales y especiales que tienen las penas en la concepción democrática del Derecho penal. ${ }^{51}$

Primeramente, analizaremos por qué no se cumple con el fin preventivo general que dice relación con la capacidad disuasoria o intimidatoria que tienen las penas. ${ }^{52}$ En este entendido, la pena busca generar un temor en el colectivo social, persiguiendo que cualquiera de las personas que lo conforman, se abstenga de la realización de una conducta ilícita porque de lo contrario será sancionado con un determinado castigo.

En este contexto preventivo no se puede situar la expulsión. Como señalamos, a propósito de la aflictividad o beneficio que pudiese importar la expulsión para ciertas y determinadas personas, ésta, desde el prisma del "beneficio", no sólo no produce la finalidad deseada por la pena en el sentido de intimidar al destinatario de la norma, sino más bien genera el efecto antónimo o contrario, constituyendo una real invitación a cometer delito. No existe la disuasión profesada, ya que la comunidad advierte o percibe que el sujeto infractor de una norma penal no será sancionado de modo alguno. ${ }^{53}$

\footnotetext{
${ }^{50}$ ROXIN, Claus, Derecho Penal Parte General. Fundamentos. La Estructura de la Teoría del Delito. Traducido: LUZÓN PEÑA, Diego Manuel; DÍAZ Y GARCÍA CONLLEDO, Miguel; DE VICENTE REMESAL, Javier, Tomo I, España: Civitas, 2007, p. 82; POLITOFF, MATUS, RAMIREZ, Lecciones, cit. nota $\mathrm{n}^{\circ} 46$, pp. 265 y ss.; CURY, Derecho, cit. nota ${ }^{\circ} 39$, p. 67.

${ }^{51}$ Cfr. QUINTERO OLIVARES, Comentarios al Código Penal, cit. nota $\mathrm{n}^{\circ}$ 16, p. 664; BAUCELLS I LLADÓS, Joan, "El derecho penal ante el fenómeno inmigratorio", Revista de Derecho y Proceso Penal, $\mathrm{N}^{\mathrm{o}} 13$ (2005), pp. 45-61, p. 61; TERRADILLOS BASOCO, "Las políticas penales europeas de inmigración”, en RUÍZ RODRÍGUEZ, Luis Ramón (Dir.), Respuestas Internacionales a los retos de la seguridad, Valencia: Tirant, 2009, p. 118.

52 POLITOFF, MATUS, RAMIREZ. Lecciones, cit. nota n ${ }^{\circ} 46$, pp. 59 y ss.; CURY, Derecho, cit. nota $n^{\circ}$ 39, p. 73; NOVOA, Curso, cit. nota n 39, p. 266; GARRIDO MONTT, Derecho, cit. nota no 39, p. 74.

${ }^{53}$ Una opinión en contrario puede verse en CUGAT MAURI, Miriam, "La expulsión de extranjeros: política migratoria y funciones del Derecho Penal", Revista de Derecho y proceso penal, No 6 (2001), pp. 23-37, p. 27. Considera que la expulsión no se opone a la función preventivo-general sino que puede contribuir eficazmente a reforzar el efecto de contramotivación de la intención criminal. "Si partimos de que buena parte del problema social que subyace en el sector de población de los inmigrantes ilegales que delinquen es el de los extranjeros que pretenden permanecer en nuestro país a cualquier precio y que recurren al delito como medio de subsistencia, es evidente de que el mensaje legal de que la comisión de un delito esta conminada con la expulsión ataca de raíz el móvil principal de este tipo de criminalidad:
} 
SALINERO, Sebastián. "La expulsión de extranjeros en el derecho penal. Una realidad en España, una posibilidad en Chile”.

Además, como indicamos, la expulsión no da cumplimiento a los fines preventivoespeciales que debiese rodear a toda pena. ${ }^{54}$ En efecto, la expulsión está distante de hacer efectiva en la persona del delincuente extranjero la finalidad reeducadora y resocializadora de las penas. ${ }^{55} \mathrm{Si}$ bien es cierto, que con la expulsión existe de alguna forma, el cumplimiento de una finalidad preventivo especial negativa, ${ }^{56}$ dado que se incapacita o inocuiza al sujeto de la posibilidad de cometer algún nuevo delito en España o en un futuro en Chile, de modo alguno, podemos encontrar en esta institución una orientación positiva, por carecer de la posibilidad de integrar socialmente al delincuente extranjero. ${ }^{57}$ Como argumenta Cancio Meliá, no se trata de que el colectivo en cuestión (extranjeros) tenga peor o mejor pronóstico con carácter general, sino de cortar el acceso de raíz de los integrantes de ese colectivo, sin distinción alguna, a una evaluación de su peligrosidad criminal. Lo criticable no es que no sea posible reinsertar a los extranjeros sin situación administrativa de permanencia regular, sino que, desde un principio se excluye respecto de ellos tal fin de la pena. ${ }^{58}$

A su vez, aparte de no cumplir con los fines de la pena, no se puede calificar como tal, por conculcar un principio rector del derecho penal, el de proporcionalidad. Es decir, cuando el extranjero no residente legalmente en el territorio de un Estado es condenado por un delito, y luego se le sustituye por la expulsión la pena privativa de libertad, se le expulsa sin posibilidad de retorno por un tiempo único y total que en muchos casos será superior a la pena privativa de libertada sustituida. Este plazo no es y no será susceptible de una menor cuantificación, atendido la naturaleza del delito, el desarrollo o iter criminis, autoría o participación o pronóstico favorable del delincuente. Es claro que en el evento de afirmar que la expulsión es una pena, ésta no guarda ninguna relación con la culpabilidad del delincuente en el hecho. ${ }^{59}$ Sin perjuicio de lo precedentemente expuesto, el PLMMA, según nuestra interpretación, supera esta desproporcionalidad entre la pena sustituida y el plazo de prohibición de retorno, dado que la prohibición de regresar a Chile sería por el mismo tiempo de la pena sustituida.

quedarse en el país, y por lo tanto puede ser un eficaz recurso intimidatorio"; MONCLÚS MASÓ, "Hacia una política criminal", cit. nota $n^{\circ} 47$, p. 344. Estima que en algunos casos la expulsión puede cumplir con el objetivo de prevención general en mayor medida que la amenaza de una pena privativa de libertad.

${ }^{54}$ POLITOFF, MATUS, RAMIREZ. Lecciones, cit. nota ${ }^{\circ} 46$, pp. 63 y ss.; CURY, Derecho, cit. nota $n^{\circ}$ 39, p. 68; GARRIDO MONTT, Derecho, cit. nota n ${ }^{\circ} 39$, p. 75.

${ }^{55}$ SOUTO GARCÍA, Eva María, "Algunas notas sobre la función del derecho penal en el control de los flujos migratorios: especial referencia a la medida de expulsión”, en FARALDO, Patricia; PUENTE, Luz María; SOUTO, Eva María (Coord.), Derecho penal de excepción: terrorismo e inmigración, Valencia: Tirant, 2007, pp. 289-322, p. 311.

${ }^{56}$ Cfr. ASÚA BATARRITA, "La expulsión del extranjero", cit. nota no 34, p. 80. Estima que ni siquiera se cumple con una prevención especial negativa, por cuanto el extranjero, luego de ser expulsado, es muy posible que intente regresar y mantener una estancia clandestina, en la que el delito puede continuar siendo el medio de vida.

${ }^{57}$ Cfr. CUGAT MAURI, "La expulsión de extranjeros", cit. nota $n^{\circ}$ 53, p. 31. "En suma, y a pesar de que a primera vista pueda ser criticable que lo único que se garantiza es que el extranjero no vuelva a delinquir en nuestro país, una reflexión en profundidad sobre el problema nos hace pensar que quizás este sea el supuesto principal en el que debe evitarse la comisión de delitos, puesto que por lo general en su país de origen desaparece la necesidad del sujeto de delinquir y por lo tanto, la del derecho a prevenir".

${ }^{58}$ CANCIO MELIÁ; MARAVER GÓMEZ, "El derecho penal español ante la inmigración", cit. nota $n^{\circ}$ 18, p. 390; En el mismo sentido MUÑOZ CONDE, Francisco; GARCÍA ARÁN, Mercedes, Derecho Penal. Parte General, Valencia: Tirant, $7^{\mathrm{a}}$ Ed., 2007, p. 567.

${ }^{59}$ Estiman, entre otros, que la expulsión viola el principio de proporcionalidad MUÑOZ LORENTE, "La expulsión del extranjero", cit. nota n 13, p. 464; DÍAZ Y GARCÍA CONLLEDO, Miguel, Protección y expulsión de extranjeros en Derecho penal, Madrid: La Ley, 2007, p. 627, quien además sostiene que la prohibición de entrada a España para el extranjero expulsado puede llegar, incluso, a 15 años. 
Por otro lado, hay quienes argumentan que estamos frente a un sustitutivo penal, aunque considera que la sustitución es una medida alternativa a la prisión. ${ }^{60}$ Otros, en esta misma línea, consideran que es un sustitutivo penal sui generis, en el que están presentes no sólo consideraciones de política criminal de acuerdo a los fines específicos del Derecho penal, sino también y de manera muy destacada, consideraciones de política de control de los flujos migratorios. ${ }^{61}$

Siguiendo con el análisis, se estima que tampoco nos encontramos frente a un sustitutivo penal, porque no se cumple con los requisitos y finalidades inherentes a esta institución. La sustitución en el caso de España tiene como requisito esencial el que la pena impuesta sea privativa de libertad de duración inferior a un año, o excepcionalmente dos, sin que rija aquí limitación alguna añadida en función de la suma de la pena con otras que se impongan al sujeto en la misma sentencia. Se requiere además que el penado no sea un reo habitual según la definición de habitualidad que contiene el art. 94 del CPe. Si se cumplen estos requisitos el Juez o el Tribunal podrá proceder a la sustitución en la misma sentencia o posteriormente en auto motivado, pero antes del inicio de la ejecución. ${ }^{62}$ Por otra parte, la finalidad de la sustitución es la prevención especial positiva, es decir, la socialización del condenado en ciertos supuestos de delincuencia no grave, por ello se dota al juez de un flexible instrumento de evitación de los efectos desocializadores de las penas cortas privativas de libertad. Entendida así la sustitución de la pena, la expulsión le es ajena en contenido y fines, pese a su ubicación orgánica. ${ }^{63}$

Más difícil es la figura chilena, porque las razones que impedirían calificar a la expulsión como un sustitutivo penal, la podemos centrar en dos puntos principales: a) El PLMMA, entre otras cosas, concibe las penas sustitutivas desde un prisma de prevención especial positivo, en donde se persigue un castigo enérgico del delincuente, pero resocializador, ${ }^{64}$ circunstancia esta última, que desde el punto de vista material sería inalcanzable con la expulsión; y b) Según el proyecto, es una finalidad de las penas sustituibles, la de evitar la reincidencia delictual, ${ }^{65}$ y con la expulsión nadie puede asegurar que el extranjero no cometa otro delito en su propia tierra o en otro país.

Un cuarto grupo, posiblemente siguiendo la jurisprudencia del Tribunal Supremo Español, señala que la expulsión es una medida de seguridad. ${ }^{66}$

${ }^{60}$ POLAINO NAVARRETE, Miguel, La reforma penal española de 2003. Una valoración crítica, Madrid: Tecnos, 2004, p. 58.

${ }^{61}$ TORRES FERNÁNDEZ, María Elena. "La expulsión de extranjeros condenados a penas privativas de libertad inferiores a seis años. Comentario de la STS de 8 de julio de 2004 a propósito de la reforma operada por la LO 11/2003", Revista del poder judicial, No 76 (2004), pp. 231-245, p. 236: "Por su caracterización legal, la expulsión de extranjeros supone, en cualquier caso, un tratamiento más beneficioso que el cumplimiento de la pena privativa de libertad, pues evita la entrada en la cárcel, con todos los efectos negativos que ello implica para el penado, siendo la prisión la pena más grave de las previstas en el CP. En este sentido es, de facto, un sustitutivo penal."

${ }^{62}$ Véase art. $88 \mathrm{CP}$. Son sustitutos las penas de multa y trabajos en beneficio de la comunidad.

${ }^{63}$ La sustitución de la pena está tratada sistemáticamente en la Sección Segunda, Capítulo Tercero, Título Tercero, Libro Primero, bajo el epígrafe "De la sustitución de las penas privativas de libertad".

${ }^{64}$ Véase PLMMA, p.3.

${ }^{65}$ Véase PLMMA, p.4.

${ }^{66}$ DÍEZ RIPOLLÉS, José Luis, Derecho Penal Español. Parte General. En esquemas. Valencia: Tirant, 2007, p. 607; MELÓN MUÑOZ, Alfonso, "La expulsión del territorio nacional en el ámbito de la extranjería", Manuales de formación continuada, No 39 (2006), pp. 75-118, p. 95. 
SALINERO, Sebastián. "La expulsión de extranjeros en el derecho penal. Una realidad en España, una posibilidad en Chile".

Para el caso español como para el chileno, consideramos que no nos encontramos ante una medida de seguridad. Esta afirmación se funda en diversos motivos, pero quizás, el argumento mas poderoso para negar la presencia de una medida de seguridad es de naturaleza teleológico, en el cual, la expulsión no responde a los fines propios de las medidas de seguridad que tanto la doctrina propugna como privativas de su esencia. En efecto, no nos encontramos frente a una medida que cumpla con una finalidad "correctiva y de aseguramiento", propia de toda medida de seguridad. ${ }^{67}$ No se logra la prevención especial positiva, al no existir tratamiento terapéutico sobre el penado que permita su curación, o a lo menos su control, de manera de lograr su reinserción en el medio social.

Otro sector clasifica la expulsión también como de naturaleza híbrida, penaladministrativa, vale decir, es una sanción administrativa que sustituye una sanción penal. ${ }^{68}$ También la doctrina -reciente- señala lisa y llanamente que la expulsión es una sanción de naturaleza administrativa. ${ }^{69}$

Tampoco se estima que nos encontramos frente a una institución de naturaleza híbrida penal-administrativa, o lisa y llanamente frente a una sanción administrativa. Si bien la expulsión puede tener su origen en el derecho administrativo -español o chileno- y específicamente en la Ley de Extranjería de los respectivos países, su localización orgánica no responde a la existencia de una sanción que tenga la calidad de administrativa. ${ }^{70}$ Pensar lo contrario, implica recoger por el legislador penal sanciones administrativas que obedecen a otros principios rectores, ajenos al Derecho penal.

Un sexto grupo de autores viene a calificar la expulsión también como una medida de naturaleza híbrida, compartiendo características tanto de la suspensión de la pena como de la aplicación de una medida de seguridad. ${ }^{71}$ Pero como dijimos anteriormente, de manera alguna cumple los fines de las medidas de seguridad, consustanciales a su denominación.

Otros, a los cuales adscribimos, sostienen que estamos en presencia de una excepción o renuncia a la pena aplicable a una determinada especie de personas. Sería una causa de

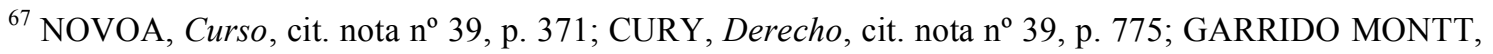
Derecho, cit. nota ${ }^{\circ} 39$, p. 344; ETCHEBERRY, Derecho, cit. nota $n^{\circ} 39$, pp. 228 y ss.

${ }^{68}$ Cfr. ASÚA BATARRITA, "La expulsión del extranjero", cit. nota $n^{\circ} 34$, p. 67."Los presupuestos y el fundamento de la expulsión prevista en el articulo 89 indican que el legislador pretendió compatibilizar la efectividad de la expulsión administrativa con la exigencia de responsabilidad penal”; SANZ MORÁN, "Reflexión de urgencia sobre las últimas reformas de la legislación penal", cit. nota n ${ }^{\circ} 18$, p. 39.

${ }^{69}$ NAVARRO CARDOSO, "Expulsión "penal" de extranjeros", cit. nota n 18, p. 170; DÍAZ Y GARCÍA CONLLEDO, Protección y expulsión de extranjeros, cit. nota $\mathrm{n}^{\circ} 59$, p. 63, señala que es una institución cuyos orígenes fueron administrativos y que responde más bien a fines administrativos. Se trata de una figura autónoma que a veces se presenta como un castigo y a veces como un premio. En principio parece que su naturaleza varia en función de a qué vaya a sustituir, sin embargo, su única razón debe verse vinculada a la política de extranjería, correctamente relacionada con el control de los flujos migratorios.

${ }^{70}$ Para profundizar sobre las diferencias entre la sanción penal y la administrativa, véase: CURY, Derecho, cit. nota $\mathrm{n}^{\mathrm{o}} 39$, pp. 104 y ss.

${ }^{71}$ MAPELLI CAFFARENA, Las consecuencias jurídicas del delito, cit. nota $n^{\circ} 35$, p. 128; Otra opinión en IZQUIERDO ESCUDERO, "Naturaleza jurídica de la sustitución”, cit. nota n 47, p. 1864: "No puede tratarse de una medida de seguridad, puesto que esta se aplica a inimputables o semi-imputables."
} 
Polít. crim. Vol. 6, No 11 (Julio 2011), Art. 4, pp. 106 - 141.

[http://www.politicacriminal.cl/Vol_06/n_11/Vol6N11A4.pdf]

levantamiento de pena cuya finalidad es excluir del sistema jurídico a una categoría de personas. $^{72}$

A nuestro entender, la expulsión es en general la renuncia al "ius puniendi" o a la posibilidad de ejecutar lo juzgado frente a determinados individuos, es la no aplicación al caso concreto de la pena señalada por el legislador frente a la comisión de un delito.

Ahora bien, si en el caso chileno vinculamos la expulsión de extranjeros a una política criminal que tiene como principal objetivo desmasificar las cárceles, de manera elocuente podemos decir que se confirma la hipótesis de que constituye una clara renuncia al ius puniendi. La administración penitenciaria o el buen funcionamiento de las cárceles chilenas no puede constituir un valor por si solo que esté por sobre el deber del Estado de ejercer el poder social de castigo sobre el infractor de la norma penal.

Además, esta renuncia al ius puniendi es absolutamente reprochable por la amplitud que puede alcanzar. Una primera crítica que se puede hacer, es que podría existir por parte de la judicatura una renuncia no sólo a la pena principal, sino también a la pena accesoria, con la consiguiente infracción al principio de legalidad. En la especie, al sustituir la pena de prisión por la expulsión se prescinde también de la pena accesoria, en una materia que no es meramente facultativa para el juez o tribunal. Como si esto no fuera poco, y no siendo menor a las renuncias aludidas, también se prescinde completamente de los intereses de la víctima, y en especial, de su derecho a ser reparada a causa o como consecuencia del acto delictivo. Si bien puede existir el olvido de la víctima en el juicio penal, es del todo injusto segregarla también de los resultados del mismo proceso, el que entre otras cosas, incluye en muchos casos una indemnización civil. Todo sin perjuicio de generar un efecto inverso de disuasión, donde sea la propia víctima la que se inhiba de denunciar el delito al observar que sus expectativas no son cubiertas por el Derecho penal.

Una segunda crítica al concebir la expulsión como una renuncia a la pena, es que se puede producir una confusión terminológica entre dos instituciones absolutamente diferentes entre sí, como son la expulsión y la "pena natural". En ambas se renuncia a la pena, pero su fundamento y finalidad es diversa. La pena natural, no es otra cosa, que la renuncia de la pena a causa del daño físico o moral grave del autor de un delito que haga desproporcionada la aplicación de una sanción o implique desconocimiento del principio de humanización de la sanción punitiva, cuyo objetivo o finalidad es beneficiar de alguna manera al autor del delito ${ }^{73}$ Por su parte, la expulsión obedece a razones de política de extranjería o supuestamente de administración penitenciaria, donde el legislador $-\mathrm{o}$ prelegislador- claramente no quiere que se refleje un trato beneficioso del penado. Los ejemplos que respaldan ésta aseveración para el caso español son variados: la jurisprudencia de los tribunales de manera asidua al aplicar la

72 CANCIO MELIÁ; MARAVER GÓMEZ, “El derecho penal español ante la inmigración”, cit. nota n 18, p. 414. El autor identifica esta institución con el ya conocido Derecho penal del enemigo; En este mismo sentido, RODRIGUEZ MESA, "El sistema penal", cit. nota $n^{\circ} 18$, p. 858; MIRÓ LLINARES, Política Comunitaria de inmigración, cit. nota $\mathrm{n}^{\mathrm{0}} 31$, p. 25.

${ }^{73}$ El Código Penal Alemán en su artículo 60 reconoce la pena natural como renuncia del derecho de punición estatal. La citada norma prescribe: "El tribunal puede prescindir de pena cuando las consecuencias del hecho que el autor ha sufrido son de tal gravedad que la imposición de una pena sería manifiestamente equivocada. Esto no es aplicable cuando el autor ha incurrido por el hecho en una pena privativa de la libertad superior a un año". 
SALINERO, Sebastián. "La expulsión de extranjeros en el derecho penal. Una realidad en España, una posibilidad en Chile".

pena de prisión en lugar de la expulsión, se basan en criterios de prevención o de consideración a la naturaleza del delito.

Una tercera crítica se fundamenta en la renuncia a la función protectora del Derecho penal, donde los diversos bienes jurídicos que deben ser valorados de manera distinta conforme a la importancia o preeminencia que la sociedad les ha dado (vida, libertad, etc.), son tratados en forma homóloga sin el distingo que naturalmente deben tener.

En este entendido, la crítica global a esta institución es a propósito de la extensa renuncia que genera; tanto en el plano del ejercicio del poder punitivo estatal, como el descuido victimal o del sujeto pasivo del delito, como en el plano de los fines de la pena.

Sin perjuicio de esta concepción general antes desarrollada, la expulsión especialmente revestirá un doble carácter o será de naturaleza ambigua para el caso concreto y cognitivo del penado. Según desde donde se mire, podrá ser una suspensión condicional de la pena o una retribución en su sentido clásico. Cuando tiene un componente de beneficio para el penado, como ocurre por ejemplo en el caso que sea el propio extranjero quién solicita la expulsión, será una suspensión condicional de la pena. La condición a la cual queda sujeto el extranjero es la de no regresar al país que lo expulsa en un determinado plazo. Por otro lado, la expulsión será una mera retribución cuando tenga una composición aflictiva para el penado, como cuando el penado viene de un país en guerra civil o de una precariedad o pobreza extrema. En este caso, nos referimos a una retribución en el sentido tradicional, donde no hay ni puede existir reeducación o reinserción social del condenado, sólo un castigo.

\section{2. Ámbito de aplicación objetivo}

A diferencia del prelegislador chileno que regula sólo una hipótesis de expulsión de extranjeros ilegales, el ordenamiento jurídico español contempla dos situaciones en las que la expulsión tendría cabida. Para un mejor entendimiento, analizaremos ambos contextos de manera separada.

\subsubsection{En España}

La expulsión procederá en dos casos: cuando se sustituye de toda la pena impuesta y en el caso de sustitución de una parte de la pena.

El primero de ellos, esto es, la sustitución de toda la pena impuesta, procederá cuando estemos en presencia de una sentencia judicial que imponga al extranjero una pena privativa de libertad inferior a seis años. En términos negativos, no procede la expulsión si no se impone por el juzgador una pena privativa de libertad al extranjero.

Cuando hablamos de penas privativas de libertad, sin duda, hacemos referencia a lo dispuesto en el artículo 35 del CPe, el que identifica o individualiza estas penas como: la prisión, la localización permanente y la responsabilidad personal subsidiaria por impago de multa. También es necesario precisar que la norma utiliza la voz "pena impuesta", por lo que se refiere a la pena concretamente aplicada al caso, independiente 
Polít. crim. Vol. 6, No 11 (Julio 2011), Art. 4, pp. 106 - 141.

[http://www.politicacriminal.cl/Vol_06/n_11/Vol6N11A4.pdf]

de cual sea la pena con que esté sancionado el delito en abstracto. ${ }^{74}$ Además, se aplica con independencia de la gravedad del delito, sea éste más o menos grave, siendo totalmente plausible de aplicar a condenas por una tentativa de homicidio, o de lesiones graves, o delitos violentos contra la libertad sexual.

Todo lo anterior nos lleva a presuponer que si el delito en abstracto tiene aparejada una pena superior a seis años, pero por aplicación de la normas sobre determinación e individualización de la pena, ésta es inferior a seis años, cabe la posibilidad de que sea sustituida por la expulsión. ${ }^{75}$

Una de las discusiones que se presenta, es saber si todas las penas privativas de libertad definidas en el artículo 35 del CPe son susceptibles de ser sustituidas por la expulsión. Al respecto, existe discusión doctrinal, siendo imposible establecer una regla en términos absolutos que permita aplicar la expulsión como sustituto de todas las penas privativas de libertad, salvo lo que dice relación con la pena de prisión, donde no existen dudas en torno a su sustitución.

En segundo lugar, también cabe la expulsión como sustitutivo de parte de la pena cuando el extranjero penado haya accedido al tercer grado penitenciario o cumplido las tres cuartas partes de la condena.

Antes de la reforma impetrada por LO 5/2010, en el párrafo segundo del artículo 89.1 $\mathrm{CPe}$, se regulaba la hipótesis de sustitución por la expulsión de parte de la pena que quedaba por cumplir cuando el extranjero era condenado a penas de prisión igual o superior a seis años y accedía al tercer grado penitenciario o cumplía las tres cuartas partes de la condena. La reforma sustituyó el mencionado párrafo por el que aparece actualmente en el apartado quinto que permite la sustitución del saldo de cualquier pena privativa de libertad por la expulsión, sin límite temporal de pena -ya no sólo penas iguales o superiores a seis años-, y sin límite de oportunidad procesal -en sentencia o durante su ejecución- para acordarse.

La parte de la pena que se sustituye por la expulsión es aquella parte que falta por cumplirse por haber el penado accedido al tercer grado penitenciario o haber cumplido las tres cuartas partes de la pena. Por ejemplo: Si nos encontramos frente a un extranjero no residente legalmente en España que se le condena a una pena de ocho años de prisión, la parte de la pena que se sustituye por la expulsión es un cuarto de la condena, esto es, los dos años correspondientes al último tramo de la pena, o aquella parte que le quede por cumplir tras haber accedido al tercer grado de tratamiento penitenciario.

Este nuevo apartado, más que colaborar en superar los conflictos que se presentaba en la práctica de los tribunales -idea planteada en la exposición de motivos del proyecto de ley original-, colocará nuevos problemas sobre el tapete y originará un fuerte dolor de cabeza al agente encargado de su interpretación o aplicación. En efecto, a diferencia de lo que ocurre en el caso de condenas a extranjeros sin residencia legal en España, a

\footnotetext{
${ }^{74}$ Cfr. RODRÍGUEZ CANDELA, "La expulsión del extranjero en el nuevo Código Penal”, cit. nota $n^{\circ}$ 47 , p. 60 .

${ }^{75}$ De la misma opinión, entre otros, DÍAZ Y GARCÍA CONLLEDO, Protección y expulsión de extranjeros, cit. nota $n^{\circ}$ 59, pp. 638 y ss.; FLORES MENDOZA, Fátima. "La expulsión del extranjero", cit. nota $\mathrm{n}^{\circ}$ 36, p. 118; MUÑOZ LORENTE, "La expulsión del extranjero", cit. nota no 13, p. 429; RODRÍGUEZ MESA, “El sistema penal ante el reto de la inmigración”, cit. nota nº 18, p. 276.
} 
SALINERO, Sebastián. "La expulsión de extranjeros en el derecho penal. Una realidad en España, una posibilidad en Chile".

penas de prisión inferiores a seis años y que son sustituidas por la expulsión, nada se dice en el caso de condenas a penas de prisión igual o superior a seis años. Por lo tanto, cabe preguntarse si en el caso de éstas condenas es aplicable o no este artículo 89.5. La respuesta no puede ser otra que entender la plena aplicación de esta norma legal. El fundamento de esta afirmación es de carácter formal, radica en que el artículo 89.5 utiliza la voz "cualquier pena privativa de libertad", por lo cual la pena no esta limitada ni en su naturaleza como explicamos con anterioridad, ni en su ámbito temporal. En concreto, se podría aplicar la expulsión sustitutiva incluso a una pena de prisión máxima de veinte años o a aquellas penas privativas de libertad -localización permanente y responsabilidad subsidiaria por impago de multas- que en el caso de sustitución total no proceden, siempre que se cumplan los demás requisitos legales.

También esta norma permitirá que la expulsión proceda en todos aquellos casos en que esté pendiente la condena del extranjero, ya sea por que el penado no ha purgado la pena o si ingresó a cumplirla, aún no la términa. Esta situación, lógicamente traerá aparejado como consecuencia que se ampliará el número de potenciales expulsados a todos aquellos extranjeros que aún no hayan cumplido la pena. Incluso podrán revisarse sentencias que no se pronunciarón en su momento sobre la expulsión, dado que se puede conforme al texto vigente decretar la expulsión por auto motivado posterior al laudo mismo. En nuestro parecer, esto último no será aplicable a las sentencias que se pronunciaron desfavorablemente sobre la expulsión, dado que estamos frente a un caso de cosa juzgada, quedando vedada su revisión.

Además, es necesario que el extranjero haya cumplido las tres cuartas partes de la pena o haya accedido al tercer grado penitenciario. Hasta antes de la LO 11/2003 sólo se contemplaba el supuesto que el penado hubiese cumplido las tres cuartas partes de la condena, siendo la novedad la incorporación de esta nueva posibilidad de acceso al tercer grado de tratamiento penitenciario. Sin duda, su inclusión obedece a la necesidad de tener cubierto todas los supuestos fácticos de que un extranjero pudiese evitar la expulsión.

El último requisito necesario para que opere la sustitución de parte de la pena por la expulsión es que lo solicite el Ministerio Fiscal al Juez o Tribunal respectivo. En consideración a esto, está vetado que los juzgadores de oficio apliquen esta institución. Asimismo, le queda prohibido al extranjero penado pedir su propia expulsión cuando ha dado cumplimiento a las tres cuartas partes de la condena o accede al tercer grado de tratamiento penitenciario. ${ }^{76} \mathrm{La}$ imposibilidad de que estas personas -Juzgador o extranjero penado- soliciten la sustitución de parte de la pena, obedece a la consideración de texto legal expreso que establece de manera privativa que la posibilidad de solicitar la sustitución de parte de una pena de prisión asiste únicamente al Ministerio Fiscal.

\subsubsection{En Chile}

El PLMMA prescribe como requisito para la procedencia de la expulsión, una pena igual o inferior a cinco años de presidio o reclusión menor en su grado máximo.

\footnotetext{
${ }^{76}$ MUÑOZ LORENTE, "La expulsión del extranjero", cit. nota $n^{\circ} 13$, p. 438. Estima pertinente que el extranjero penado solicite su propia expulsión en virtud de lo preceptuado en el artículo 52.2 del Reglamento Penitenciario en relación con la obligación de información a los internos extranjeros de la posibilidad de sustitución de la pena de prisión por la expulsión.
} 
La diferencia con el caso español, no sólo radica en el quantum de la pena que se sustituye -inferiores a cinco años en Chile e inferiores a seis en España-, sino también en la posibilidad de sustituir penas parciales. El proyecto sólo legisla sobre la posibilidad de que se sustituyan penas totales a imponer a un ciudadano extranjero. Además, la pena que se sustituye debe ser una privativa de libertad -presidio o reclusión-, no cabe la sustitución de una pena que no sea de esta naturaleza, por lo que no procederá en caso de penas de multa, inhabilidades, suspensiones, confinamiento, extrañamiento, relegación, etc. ${ }^{77}$ Por eso, se justificaría nuestro argumento, en orden a que en el evento de imponerse una pena accesoria a la pena privativa de libertad que se sustituirá -lo que ocurrirá en la mayoría de los casos-, se producirá también una renuncia de esta pena accesoria que correrá la misma suerte de la principal.

Al igual que el caso español, el proyecto legislativo utiliza la voz "condenado a una pena" por lo que la expulsión tendría cabida tratándose de una pena impuesta en concreto ex - post, independiente de cual sea la pena con que esté sancionado el delito en abstracto. Su eventual aplicación no se encuentra limitado ni en consideración a la gravedad del delito, grado de desarrollo del mismo, autoría o participación del extranjero en el ilícito. De esta forma, en atención a los antecedentes particulares del penado, como a una participación de éste tendiente a esclarecer los hechos imputados o en velar por la reparación de la víctima del delito, siempre que alguna de estos estados sean reconocidas por la judicatura como aminorante de responsabilidad penal, nos llevaría a sostener que se podrían sustituir por la expulsión las penas de un gran número de delitos graves: homicidio simple consumado, robo con violencia, etc. En la práctica, una gran parte de los ilícitos de la parte especial podrían ser susceptibles de que sus penas sean sustituidas por la expulsión. En ese escenario, muchos victimarios podrán encontrar un verdadero beneficio en la expulsión, incluso mayor que la que se contempla en la remisión condicional de la pena -vigente o que se propone en el PLMMA-, al no estar obligados a ciertas cargas como el pago de indemnizaciones y costas del proceso penal.

Como dijimos, sólo se sustituye por la expulsión las penas privativas de libertad, sea de presidio o reclusión -la primera sujeta al condenado al régimen de trabajos del establecimiento penitenciario y la segunda no impone tal gravamen adicional- ${ }^{78}$, por lo que claramente no serían sustituibles las penas de prisión en caso de las faltas reguladas en el Libro Tercero del Código Penal chileno.

Por último, el PLMMA sólo contempla un momento procesal para que el juez o tribunal acuerde la expulsión del extranjero: no puede ser otro que no sea al momento de pronunciar la sentencia. El prelegislador sanciona una situación que no se encuentra en ejecución -el extranjero aún no ha entrado a cumplir la pena privativa de libertad impuesta-, sino que es un hecho que está por ocurrir. Por eso, a diferencia del caso español, sólo se podrían sustituir las penas privativas a imponerse, no todas aquellas cuyo cumplimiento esté pendiente. Por lo tanto, la oportunidad procesal para impetrar esta regla sería al momento que el sentenciador dicte su sentencia condenatoria. En ese mismo instante de dictar la sentencia y dependiendo en definitiva de la discrecionalidad del juez, quién podrá o no decretar la expulsión sustitutiva, se podría dar una dicotomía que pensamos no tiene solución con esta denominada regla especial: por un lado se

\footnotetext{
${ }^{77}$ Véase artículos 21 y ss. del Código Penal chileno.

${ }^{78}$ Véase artículos 32 del Código Penal chileno.
} 
SALINERO, Sebastián. "La expulsión de extranjeros en el derecho penal. Una realidad en España, una posibilidad en Chile”.

podría dar la paradoja de expulsar a un extranjero ilegal que comete un delito de robo y ordenar a otro extranjero ilegal el cumplimiento de una pena de privativa de libertad por un delito de menor gravedad.

\section{3. Ámbito de aplicación subjetivo}

Los requisitos subjetivos para que opere la expulsión judicial decretada en un proceso penal, tanto en España como en Chile, están referidos a que el sujeto sancionado con esta consecuencia jurídico-penal debe reunir una calidad o estado especial. Esta calidad, no ajena de críticas, ${ }^{79}$ conforme lo preceptuado en el artículo 89 del CPe y 35 del PLMMA, es la de ser extranjero no residente legalmente en el respectivo país. Esta calidad exigida al sujeto activo de la conducta punible es el único requisito subjetivo formal impuesto por el legislador español y el prelegislador chileno, no se exige ningún otro requisito. En otros términos, para proceder a la sustitución se requiere que el sujeto sea un extranjero residente ilegal; como bien apunta Muñoz Lorente poco importa si es primera vez que delinque, si es un reo habitual o no, si está enfermo, si es un toxicómano o cuáles son sus circunstancias personales y familiares o, finalmente, cuál es el pronóstico de reinserción social que se deriva de su persona. ${ }^{80}$

El sujeto activo de esta sanción debe ser un "extranjero", por tanto, quedan excluidos de la aplicación de lo prevenido en el artículo 89 del CPe o del artículo 35 del PLMMA, y por consiguiente, de la posibilidad de ser expulsados, las personas que detentan la nacionalidad española (art. 17 a 28 del Código Civil) para el caso de España, y la nacionalidad chilena (art. 10 Constitución Política de la Republica de Chile) en el caso de Chile.

Por otra parte, el término "extranjero no residente legalmente" no está definido en el Código Penal español o chileno, de ahí que entendamos que estamos frente a una ley penal en blanco y que tenemos que llenar esta laguna recurriendo a la Ley de Extranjería de alguno de estos dos países en estudio, específicamente a la Ley Orgánica 4/2000, sobre Derechos y Libertades de los Extranjeros en España y su Integración Social, ${ }^{81}$ o Ley de Extranjería de Chile y su respectivo Reglamento. ${ }^{82}$

No obstante, estas leyes no definen en forma literal lo que debemos entender por "extranjero no residente legalmente", sino más bien define este término de manera positiva, señalando quienes son los extranjeros con residencia legal $\mathrm{y}$, en consecuencia, los extranjeros que no pueden ser expulsados judicialmente por la comisión de un delito, pero sí en forma administrativa. El artículo 30 bis de la Ley de Extranjería española, indica, que "son residentes los extranjeros que se encuentren en España y sean

\footnotetext{
${ }^{79}$ BAUCELLS I LLADÓS, Joan, “El derecho penal ante el fenómeno inmigratorio”, Revista de Derecho y Proceso Penal, $\mathrm{N}^{\mathrm{o}} 13$ (2005), pp. 45-61, p. 61. Señala que esta calificación plantea problemas de constitucionalidad puesto que el hecho de ser extranjero y no poseer el permiso de residencia no es un criterio que -de acuerdo con la jurisprudencia del Tribunal Constitucional- pueda fundamentar un trato discriminatorio.

${ }^{80}$ MUÑOZ LORENTE, “La expulsión del extranjero”, cit. nota nº 13, p. 435.

${ }^{81}$ Es la norma que regula la entrada y la estancia de los extranjeros en el territorio español, así como los derechos y libertades que se le reconocen. Su actual reglamento de desarrollo fue aprobado por el Real Decreto 2393/2004, de 30 de diciembre.

${ }^{82}$ Decreto Ley $N^{\circ} 1094$, de 1975, y Decreto Supremo No 597, de 1984. Estas normas regulan la entrada y la estancia de los extranjeros en el territorio chileno, así como los derechos y libertades que se le reconocen
} 
titulares de una autorización para residir"; los residentes podrán encontrarse en la situación de residencia temporal o residencia permanente. ${ }^{83}$ La residencia temporal autoriza la permanencia en España hasta por cinco años, cumplido el resto de los requisitos señalados en la ley. ${ }^{84}$ Por su parte, la residencia permanente es la situación que autoriza a residir en España indefinidamente y trabajar en igualdad de condiciones que los españoles. ${ }^{85}$

A su vez, los artículos 19, 22 y 41 de la Ley de Extranjería chilena definen quienes son residentes. El primero se refiere a los residentes oficiales, entendiéndose por aquellos los miembros del Cuerpo Diplomático y Consular acreditados ante el Gobierno y los de organizaciones internacionales reconocidos por Chile, a quienes se concedan visaciones diplomáticas u oficiales. La segunda disposición, o sea, el 22, se refiere a que también son residentes las personas con visaciones, ya sea: residente sujeto a contrato, residente estudiante, residente temporario y residente con asilo político o refugiado. Para efectos de esta disposición, los requisitos para cada visación son los siguientes: a) Residente sujeto a contrato: Se otorga visación de residente sujeto a contrato a los extranjeros que viajen a Chile con el objeto de dar cumplimiento a un contrato de trabajo. La misma visación se puede otorgar a los extranjeros que se encuentren en territorio chileno y se radiquen en ese país para dar cumplimiento a un contrato de trabajo. La visación sujeta a contrato puede tener una vigencia de hasta dos años y puede ser prorrogada por períodos iguales. El residente sujeto a contrato podrá solicitar su permanencia definitiva al cumplir dos años de residencia; ${ }^{86}$ b) Residente estudiante: Se otorga visación de residente estudiante al extranjero que viaje a Chile con el objeto de estudiar en establecimientos del Estado o particulares reconocidos por éste, o en centros u organismos de estudios superiores o especializados. Igualmente podrá otorgarse a los extranjeros que, encontrándose en Chile, acrediten haberse matriculado en alguno de estos establecimientos. Dicha visación tendrá una vigencia máxima de un año y podrá ser renovada por períodos iguales, en forma sucesiva y gratuita; ${ }^{87}$ c) Residente temporario: Esta visación se otorga al extranjero que tenga el propósito de radicarse en Chile, siempre que acredite vínculos de familia o intereses en este país o cuya residencia sea estimada útil o ventajosa, visación que se hará extensiva a los miembros de su familia que vivan con él. También, se podrá conceder esta visación a los ex residentes que, a lo menos, hubieren permanecido un año en Chile y a los que hubiesen tenido anteriormente permanencia definitiva y ésta hubiere caducado, por haber permanecido de manera ininterrumpida por un plazo superior a un año fuera de Chile. La visación de residente temporario tiene una vigencia máxima de un año y podrá prorrogarse por una sola vez, por igual período. El titular de visación de residente temporario que completare un año de residencia en tal calidad, podrá solicitar su permanencia definitiva y si completare dos años de residencia en Chile, estará obligado a solicitarla. En caso de no hacerlo, deberá abandonar el país, ${ }^{88} \mathrm{y}$; d) Residente con asilo político o refugiado: En

\footnotetext{
${ }^{83}$ Véase art. 30 bis 2 de la LEX.

${ }^{84}$ Véase art. 31 LEX.

${ }^{85}$ Véase art. 32 LEX; Tendrán derecho a residencia permanente los que hayan tenido residencia temporal durante cinco años de forma continuada. Se considerará que la residencia ha sido continuada aunque por períodos de vacaciones u otras razones que se establezcan reglamentariamente hayan abandonado el territorio nacional temporalmente. Con carácter reglamentario y excepcionalmente se establecerán los criterios para que no sea exigible el citado plazo en supuestos de especial vinculación con España.

${ }^{86}$ Véase art. $23 \mathrm{LECH}$.

${ }^{87}$ Véase art. 27 LECH.

${ }^{88}$ Véase art. 29, 30 y 31 LECH.
} 
SALINERO, Sebastián. "La expulsión de extranjeros en el derecho penal. Una realidad en España, una posibilidad en Chile".

general, podemos decir que se le concede visación de asilo político a los extranjeros que, en resguardo de su seguridad personal y en razón de las circunstancias políticas predominantes en el país de su residencia, se vean forzados a recurrir ante alguna misión diplomática chilena solicitando asilo o ingresen irregularmente a territorio chileno por las mismas razones antes expresadas. A su vez, se concede visación de refugiado a los extranjeros se encuentre en alguna de las situaciones previstas en las Convenciones internacionales vigentes en Chile. ${ }^{89}$

En tercer lugar, conforme lo define el artículo 41 de la Ley de Extranjería chilena, un extranjero se puede encontrar en situación de residencia definitiva, cuando se le concede permiso para radicarse indefinidamente en Chile y desarrollar cualquier clase de actividades, sin otras limitaciones que las que establezcan las disposiciones legales y reglamentarias. Este permiso se otorga por resolución del Ministerio del Interior. ${ }^{90}$

En definitiva, todos aquellos extranjeros que no gozan de permiso de residencia o las visaciones necesarias serán sujetos idóneos de ser expulsados conforme el artículo 89 del CP o artículo 35 del PLMMA si es que han cometido un delito sancionado con pena privativa de libertad.

Sin embargo, la interpretación de este término -extranjero no residente legalmente- no es pacífica, o ajena de inconvenientes o discusiones en la doctrina española. Discusiones que sin duda devendrán en la doctrina chilena de aprobarse el proyecto.

Así, si bien, como se dijo con anterioridad, podemos interpretar este término recurriendo a la respectiva ley de extranjería - española o chilena- existen ciertos estados en los que se puede encontrar un extranjero que en el caso concreto no son constitutivos de residencia, generándose el consiguiente problema de la procedencia del artículo 89 del CPe o artículo 35 del PLMMA.

En efecto, el artículo 29 de la Ley de Extranjería española nos señala que un extranjero podrá encontrarse en España en las situaciones de estancia o residencia. Esta situación de estancia es la que se podrían encontrar los estudiantes y turistas no comunitarios, y consiste en general, en la autorización que da la administración a un extranjero para permanecer en territorio español por un tiempo determinado. Transcurrido ese tiempo será preciso obtener una prórroga de estancia o una autorización de residencia. Tratándose en particular de los turistas no comunitarios podrán permanecer un período máximo de 90 días (sin perjuicio de las prórrogas que conceda la Administración), y por su parte, los estudiantes están autorizados a permanecer en territorio español, el tiempo de duración de los cursos en que estuvieran matriculados. ${ }^{91}$

\footnotetext{
${ }^{89}$ Véase art. 34 y ss. LECH.

${ }^{90}$ Véase art. 41 y ss. LECH.

${ }^{91}$ Véase art. 30 de la LEX; Situación de estancia; 1. Estancia es la permanencia en territorio español por un período de tiempo no superior a 90 días, sin perjuicio de lo dispuesto en el artículo 33 para los estudiantes; 2. Transcurrido dicho tiempo, para permanecer en España será preciso obtener o una prórroga de estancia o una autorización de residencia; 3. En los supuestos de entrada con visado, cuando la duración de éste sea inferior a tres meses se podrá prorrogar la estancia, que en ningún caso podrá ser superior a tres meses, en un período de seis meses; 4. En los supuestos de entrada sin visado, cuando concurran circunstancias excepcionales que lo justifiquen, podrá autorizarse la estancia de un extranjero en el territorio español más allá de tres meses. A su vez, el artículo 33 de la LEX regula el régimen especial de los estudiantes, señalando; 1.Tendrá la consideración de estudiante el extranjero cuya venida a
} 
Analizadas las situaciones de estancia, corresponde que resolvamos si aquellos sujetos que tienen esta autorización son "no residentes legalmente en España" para los efectos del artículo 89 del CPe. Desde ya, hay que manifestar que este es un tema que en doctrina no genera consensos. Hay algunos que piensan que los extranjeros en situación de estancia son asimilables a los residentes legales y por tanto no serían sujetos de expulsión penal..$^{92}$ Empero, hay otra parte de la doctrina, a la cual nos adherimos, que entiende que la situación de estancia no es sinónima de residencia por lo que los extranjeros en esta situación pueden ser penalmente expulsados. ${ }^{93}$ Como algunas razones que justifican la posibilidad de expulsar al extranjero en situación de estancia, se pueden señalar tres motivos que aluden a la clara diferencia entre este término y el de "residencia". En primer lugar, para la Ley de Extranjería española están claramente diferenciadas las situaciones de "residencia" y "estancia" al tratarlas sistemáticamente de manera disímil, de tal manera que podemos inferir que el legislador ha querido que sean situaciones diversas y produzcan efectos distintos. En segundo lugar, por hermenéutica legal debemos entender que el término "extranjero no residente legalmente" acuñado por el legislador penal, no puede interpretarse al margen de la legislación administrativa sobre extranjería, máxime, cuando el artículo 89 del CPe tiene su origen histórico, casi de manera calcada en esa legislación y responden ambas a una única y misma política criminal. En tercer y último termino, en materia penal como limitación al ius puniendi estatal debemos interpretar los diversos preceptos normativos de manera restrictiva, quedando prohibida su interpretación analógica.

También, como señala Muñoz Lorente es obvio indicar que aquellos sujetos que se encuentran en España en situación de estancia o residencia ilegal -por haber transcurrido los noventa días de estancia legal o por haber entrado de manera

España tenga como fin único o principal el cursar o ampliar estudios o realizar trabajos de investigación o formación, no remunerados laboralmente, en cualesquiera centros docentes o científicos españoles, públicos o privados, oficialmente reconocidos; 2. La situación del extranjero en régimen de estudiante será la de estancia y la duración de la autorización será igual a la del curso para el que esté matriculado; 3. La autorización se prorrogará anualmente si el titular demuestra que sigue reuniendo las condiciones requeridas para la expedición de la autorización inicial y que cumple los requisitos exigidos por el centro de enseñanza al que asiste, habiéndose verificado la realización de los estudios; 4. Los extranjeros admitidos con fines de estudio no estarán autorizados para ejercer una actividad retribuida por cuenta propia ni ajena. Sin embargo, en la medida en que ello no limite la prosecución de los estudios, y en los términos que reglamentariamente se determinen, podrán ejercer actividades remuneradas a tiempo parcial o de duración determinada; 5. La realización de trabajo en una familia para compensar la estancia y mantenimiento en la misma mientras se mejoran los conocimientos lingüísticos o profesionales se regularán de acuerdo con lo dispuesto en los acuerdos internacionales sobre colocación au pair.

92 De esta opinión, entre otros, DÍAZ Y GARCÍA CONLLEDO, Protección expulsión de extranjeros en Derecho Penal, cit. nota $n^{\circ} 59$, p. 635. "En el supuesto de extranjeros en situación de estancia, lo que ocurre es que el sujeto no es un "residente", pero sí se encuentra autorizado para permanecer en España, por lo tanto, sí es un sujeto que podríamos denominar "legal". Entendemos que, cuando en el CP se habla de "no residente legalmente" en España, se está haciendo referencia tanto a aquellos que no tienen permiso de residencia como aquellos que no tienen permiso de estancia; es decir, a todos los que están, de uno $\mathrm{u}$ otro modo legalmente en España, esto es, a aquellos que se encuentren de modo irregular. Consideramos que debe prestarse más atención al adjetivo legal que al sustantivo residente y no expulsar penalmente a aquel que tenga la situación de estancia."; FLORES MENDOZA, "La expulsión del extranjero", cit. nota $\mathrm{n}^{\mathrm{o}}$ 36, pp. 113 y ss. A propósito del término "extranjero no residente legal" propone una interpretación no en sentido estricto.

${ }^{93}$ Son partidarios de ésta opinión, entre otros, p. 4; RODRÍGUEZ MESA, "El sistema penal ante el reto de la inmigración", cit. nota $n^{\circ}$ 18, p. 275; LAFONT NICUESA, Luis, "La expulsión de extranjeros", en Cuadernos penales José María Lidon, U. de Duesto, Bilbao, 2004, p. 169; MUÑOZ LORENTE, "La expulsión del extranjero", cit. nota n 13, p. 448; ASÚA BATARRITA, "La expulsión del extranjero", cit. nota $\mathrm{n}^{\mathrm{o}} 34$, p. 70 . 
SALINERO, Sebastián. "La expulsión de extranjeros en el derecho penal. Una realidad en España, una posibilidad en Chile”.

clandestina-, también serán susceptibles de expulsión como ocurre habitualmente en los casos de inmigrantes ilegales que carezcan de permiso o residencia o que hayan entrado en España sin visado, sin hacerlo a través de los puestos habilitados al efecto (por ejemplo, los casos de inmigrantes que arriban a territorio español en pateras) o que carezcan de cualquier clase de documentación que acredite su identidad. ${ }^{94}$

Por otro lado, la situación chilena no es más favorable que la española. A nuestro juicio, existen algunos estados en los que se puede encontrar un extranjero en Chile, como lo es la condición de "turista" que serían susceptibles de ser expulsados conforme el tantas veces mencionado artículo 35 del PLMMA. En efecto, partiendo de la premisa que la expulsión pesa sobre los hombros de todos aquellos extranjeros que no son residentes legales en Chile, y los turistas si bien podrían contar con la debida autorización de visación para permanecer legítimamente en el país por cierto lapso de tiempo, no son residentes ante los ojos de la Ley de Extranjería chilena. Así, queda de manifiesto no sólo del artículo 4 de la Ley en cuestión, que diferencia la calidad de turista de la de residente para los efectos del ingreso de extranjeros a Chile, sino también del artículo 44 que define lo que hay que entender por turista y niega absolutamente la residencia como un componente de su acepción o definición. Además, y sin ánimo de redundar, son absolutamente compatibles para la situación chilena las razones esgrimidas a propósito de la situación de estancia del caso español: en la Ley de Extranjería chilena está claramente diferenciada la situación de "residencia" de la de "turismo", al estar tratadas sistemáticamente de manera diferente, por lo que se colige que el trato del legislador es distinto. Y por último, y no menos importante, se encontraría proscrito una interpretación amplia y por vía analógica del concepto.

Para finalizar, quizás lo más criticable de lo tratado en este epígrafe, es que el factor fundamental para distinguir si el juez aplica una pena privativa de libertad o ésta se sustituye por la expulsión, no es la culpabilidad del sujeto activo del delito, sino la calidad administrativa con que el extranjero se encuentra en Chile. Paradojalmente, un extranjero que cumple prolijamente con nuestra legislación de extranjería, renueva los permisos de residencia por ejemplo, recibirá una pena privativa de libertad si comete un delito; en cambio, por el mismo delito, un extranjero poco minucioso con su situación legal Chile o deliberadamente queriendo ser ilegal, podría verse expuesto a la expulsión, lo que como vimos anteriormente, consecuencialmente le podría favorecer.

\subsection{Efectos y ejecución de la expulsión}

La sustitución de la pena privativa de libertad por la expulsión del territorio nacional tiene obviamente un primer efecto -la expulsión- pero no es el único. ${ }^{95}$ Tratándose de España, el artículo 89.2 del CPe señala, quizás, el efecto más gravoso para el extranjero, la prohibición de regresar a España por un lapso que puede variar entre cinco a diez años contados desde la expulsión, atendiendo la duración de la pena sustituida y las circunstancias personales del penado.

Antes de la reforma -LO 11/2003- el artículo 89 del CPe permitía no sólo discrecionalidad del juez o tribunal para optar en cada caso concreto por la expulsión de un extranjero no residente legalmente en España, sino que facultaba en caso de decidir aplicar la expulsión, la temporalidad de la misma, la cual oscilaba entre tres y diez años,

\footnotetext{
${ }^{94}$ MUÑOZ LORENTE, “La expulsión del extranjero”, cit. nota n ${ }^{\circ} 13$, p. 448.

${ }^{95}$ MUÑOZ LORENTE, "La expulsión de extranjeros", cit. nota no 13, p. 464.
} 
contados desde el momento de la expulsión y tenía siempre como marco referencial las características del delito. Posteriormente con la reforma no solo existía un plazo fijo de diez años, sino que las características del delito no son valoradas a la hora de que la judicatura decida impetrar la expulsión. Es decir, el plazo era siempre y como mínimo de diez años, tanto si se trata de un delito de falsedad documental como si se tratase de un delito contra la salud pública. Con la reforma de LO 5/2010, las cosas cambiaron nuevamente, el juez o tribunal puede discrecionalmente determinar el plazo de prohibición de retorno el que varía entre cinco a diez años, atendida la duración de la pena sustituida y las circunstancias personales del penado.

Por otra parte, la consecuencia de la expulsión es la salida del territorio español, y del denominado espacio Schengen, ${ }^{96}$ es decir, consecuentemente, el extranjero tendrá no sólo la prohibición de ingresar a España, sino a todo el espacio Schengen. (Todos los países del Espacio Schengen, con la excepción de Noruega e Islandia que no son miembros de la Unión Europea. Suiza ratificó por referéndum su adhesión en 2005 pero a la fecha no ha implantado las medidas necesarias para su puesta en vigencia. Por otra parte, dos miembros de la UE, Irlanda y el Reino Unido han optado por permanecer fuera de la misma).

En caso de intento de quebrantamiento de la decisión judicial de expulsión y prohibición de entrada, el artículo 89.4 del CPe dispone que si el extranjero es sorprendido en la frontera será devuelto por la autoridad gubernativa (devolución), empezando a computarse de nuevo el plazo de prohibición de entrada en su integridad. En cambio, si es habido ya al interior de España, deberá cumplir las penas privativas que le fueron sustituidas. ${ }^{97}$

Otro efecto de la expulsión, es que no se mantiene la prohibición de aplicación de lo dispuesto en los artículos 80,87 y 88 del CPe. ${ }^{98}$ Nada se dice al respecto, por lo que se puede colegir que la intención del legislador español es que la pena pueda suspenderse o sustituirse conforme al régimen ordinario, cuando no se pueda llevar a efecto la expulsión.

En lo que respecta a la ejecución o materialización de la expulsión, la LO 19/2003, de veintitrés de diciembre, que reforma la Ley Orgánica del Poder Judicial, dispone la obligación de los órganos judiciales de comunicar a la autoridad gubernativa las sentencias en las que acuerden la sustitución de las penas privativas de libertad impuestas o de las medidas de seguridad que sean aplicables a los extranjeros no residentes legalmente en España por la expulsión de los mismo del territorio nacional. En estos casos, la sentencia que acuerde la sustitución deberá cumplirse en el plazo más breve posible $\mathrm{y}$, dentro de los treinta días siguientes a la resolución de expulsión, pero

\footnotetext{
${ }^{96}$ La Directiva 2001/40/CE, de 28 de mayo de 2001, establece el reconocimiento mutuo de las decisiones en materia de expulsión de nacionales de terceros países.

${ }^{97}$ MUÑOZ LORENTE, “La expulsión de extranjeros", cit. nota n ${ }^{\circ} 13$, p. 465. Al respecto, explica que la figura de la expulsión y de la devolución son totalmente distintas y en consecuencia también su regulación en la Ley de Extranjería. En este sentido, la devolución no exige la sustanciación de ningún expediente administrativo, mientras que la expulsión sí, y en consecuencia resulta mucho más rápida, expeditiva, fulminante y contundente porque sólo requiere que sea decretada; En mismo sentido NAVARRO CARDOSO, "Expulsión penal de extranjeros", cit. nota n 18, p. 178.

${ }^{98}$ Normas referidas a la posibilidad de sustituir las penas privativas de libertad por otras menos gravosas y de suspender las penas privativas de libertad; Antes -con LO 11/2003- , el artículo 89.1 del CPe., mantenía la imposibilidad de la aplicación de lo dispuesto en los artículos 80, 87 y 88 del CPe.
} 
SALINERO, Sebastián. “La expulsión de extranjeros en el derecho penal. Una realidad en España, una posibilidad en Chile”.

mientras tanto dispondrá la ejecución de las penas privativas de libertad o medidas de seguridad originariamente impuesta en tanto la autoridad gubernativa procede a ejecutar la expulsión. ${ }^{99}$

Por último, en caso de que acordarse la sustitución de la pena privativa de libertad por la expulsión, y ésta no pudiera llevarse a efecto, como sucedería en el caso de sujetos que se desconozca su lugar de procedencia o el país de origen no lo recibe por cualquier motivo que sea, se procederá al cumplimiento de la pena privativa de libertad originariamente impuesta o del período de condena pendiente. ${ }^{100}$ Todo sin perjuicio del derecho del extranjero al régimen ordinario de sustitución y suspensión de penas.

Hay que recordar que la pena originariamente impuesta - privativa de libertad- no se extingue, sino que simplemente queda en suspenso en el período que media entre que se decretó la expulsión y el del vencimiento del plazo de prohibición de retorno. ${ }^{101}$

Para finalizar, es necesario señalar que una vez acordada la expulsión, comporta el archivo de cualquier procedimiento administrativo que tuviera por objeto la autorización para residir o trabajar en España.

Por su parte, en Chile el artículo 35 del PLMMA no plantea de manera expresa un plazo de prohibición de retorno del extranjero al país. No obstante ello, estimamos que la prohibición de regreso será el mismo de la pena privativa de libertad que se sustituye. Llegamos a esta conclusión en consideración a que se sustituye por la expulsión el "cumplimiento" de una pena como indica el propio precepto legal aludido.

En Chile, el juez o tribunal no tendría discrecionalidad para determinar el plazo de prohibición de retorno del extranjero al país. Siempre será el equivalente a la pena privativa de libertad que se sustituya. Esta situación, que pudiese ser menor o de poca importancia, tiene un componente del cual carece en nuestra opinión la expulsión en el sistema español. En el caso chileno la expulsión respetaría el principio de proporcionalidad: donde el tiempo de prohibición de regreso al país, derivado de la expulsión, en caso alguno sería mayor al tiempo de la pena privativa de libertad inicialmente impuesta. En España -actualmente- no existe en todos los casos la debida correspondencia entre el tiempo de prohibición de regreso y la culpabilidad por el hecho: independiente de la pena privativa de libertad impuesta en sentencia, el juez o tribunal puede imponer una prohibición de regreso de cinco a diez años. Así por ejemplo, se puede dar la paradoja de imponer en la sentencia una pena privativa de libertad de un año, como ocurre frente a los conocidos casos denominados "top manta", y sustituir la pena por la expulsión con prohibición de regreso por un lapso de cinco años.

\footnotetext{
99 Véase Disposición adicional $17^{\circ}$ LO 19/2003; El proyecto de reforma de Código penal 2009, para asegurar la expulsión, contempla en su art. 89.6 la posibilidad de que el extranjero ingrese a centro de internamiento de extranjeros, en los términos y con los límites y garantías previstas en la Ley para la expulsión gubernativa.

${ }^{100}$ QUINTERO OLIVARES, Comentarios al Código Penal, cit. nota n ${ }^{\mathrm{o}}$ 16, p. 741.

101 ROSA CORTINA, José Miguel, "La expulsión de los extranjeros no residentes legalmente condenados a pena privativa de libertad inferior a seis años tras la reforma 11/2003, de 29 de septiembre", La Ley: Revista jurídica española de doctrina, jurisprudencia y bibliografía, No 3 (2004), pp. 1917-1927, p. 1924.
} 
En Chile, desde el ámbito espacial la medida tiene efecto sólo a nivel local, esto es, se prohibiría el regreso del extranjero a cualquier parte del territorio de la República o que sea parte de su soberanía.

En lo que respecta al quebrantamiento de lo resuelto por la judicatura chilena, al igual que en el caso español, tendrá su origen en el evento que el extranjero intente ingresar o lisa y llanamente ingrese a territorio chileno. El PLMMA dedica un título, específicamente el quinto que lleva por nombre "Del incumplimiento y quebrantamiento", el que a nuestro entender no le sería aplicable a los extranjeros: las razones no son sólo de orden sistemático formal -el quebrantamiento es regulado de manera previa a la expulsión, entre los artículos 24 y 32 del PLMMA- sino también de orden sustantivo, por cuanto las disposiciones sobre incumplimiento y quebrantamiento se refieren en forma expresa a las penas sustitutivas -la expulsión es una regla especial para el PLMMA - que están constituidas por: la remisión condicional, reclusión parcial, libertad vigilada y libertad vigilada intensiva. ${ }^{102}$ La pregunta que cabe hacerse es si frente a este vacío del proyecto del ejecutivo, podríamos recurrir a las reglas generales de la parte general del Código Penal chileno, o sea a las disposiciones previstas en los artículos 90 y 91 . Respecto del primero, la respuesta es negativa de manera tajante, la expulsión no se encuentra en el catálogo de penas susceptibles de quebrantarse. Pensar lo contrario, es una clara infracción al principio nullum crime sine lege. En relación al segundo artículo, estimamos que podría en ciertos y determinados casos ser recogido el quebrantamiento de la expulsión por el artículo 91, ya que la citada norma hace alusión a la hipótesis que una persona luego de ser condenada por sentencia ejecutoriada, durante el cumplimiento de la condena, cometiera un crimen o simple delito. Piénsese del extranjero que no obstante existir una orden de expulsión, impuesta por sentencia ejecutoriada, intenta ingresar o ingresa a Chile por un paso fronterizo no autorizado o con documentos falsificados. Frente a este caso, estamos ante una persona que cometió un delito -artículo 68 o 69 de la Ley de Extranjería chilena- durante el tiempo de ejecución de la condena de expulsión y por tanto, le sería aplicable el artículo 91 del Código Penal chileno, de cuyo resultado se sigue que el extranjero debería entrar a cumplir la pena inicialmente sustituida por la expulsión y la pena correspondiente a la comisión del nuevo delito. ${ }^{103}$

Otra importante pregunta por resolver, dice relación con determinar si los extranjeros sin residencia legal en Chile, luego de ser condenados por un delito, pueden ser acreedores, de manera prioritaria o con preferencia a la expulsión, de algunas penas sustitutivas del proyecto -como la remisión de la pena o la reclusión parcial-. Consideramos que por razones de igualdad y principio de mínima intervención o última ratio del derecho penal, los extranjeros, cualquiera sea su condición en el país regulares o no- tendrían derecho al régimen ordinario de penas sustitutivas como cualquier persona. El Gobierno de Chile, si lo que quiere es asegurar la expulsión del extranjero irregular, siempre tendrá el instituto de la expulsión contemplada en la Ley de Extranjería (carácter administrativo).

Para concluir, si se ordenare la expulsión del extranjero, deberá oficiarse al Departamento de Extranjería del Ministerio del Interior, para efectos de que lleve a cabo la implementación de esta medida, debiendo mantenerse al extranjero irregular bajo la

\footnotetext{
${ }^{102}$ Véase arts. 1 y 24 a 32 del PLMMA

${ }^{103}$ Véase arts. 90 y 91 del Código Penal chileno.
} 
SALINERO, Sebastián. "La expulsión de extranjeros en el derecho penal. Una realidad en España, una posibilidad en Chile”.

custodia de Gendarmería de Chile en el tiempo que medie entre la dictación de la sentencia condenatoria y la expulsión definitiva del territorio de la República.

\section{Conclusiones}

7.1. El Derecho Penal tiene como finalidad la protección de bienes jurídicos, por lo que en caso de que ellos corran peligro o sean efectivamente lesionados, el Derecho debe reaccionar naturalmente con una pena o una medida de seguridad, las cuales cumplen distintas finalidades, tales como, la retribución, la prevención -general y especial- el aseguramiento y la corrección.

Por su parte, la expulsión no siendo una pena o una medida de seguridad, no cumple ni puede cumplir los fines de las mismas, toda vez que en términos generales no es más que una renuncia al ius puniendi para fines que le son ajenos, como es la política de extranjería o la administración penitenciaria.

En términos especiales la expulsión es de naturaleza ambigua, pudiendo ser: una suspensión condicional de la pena o una retribución en su sentido clásico. Que sea una o la otra, no va a depender de las características del delito o de la gravedad de la pena sustituida, sino que en forma exclusiva de las circunstancias personales del extranjero penado. Así, para un procedente de un país pobre que viene a España o Chile huyendo de la miseria de su tierra y esperanzado en una vida mejor, la expulsión tendrá un componente aflictivo. En cambio para un extranjero de un país con calidad de vida mejorada que quiere probar suerte en el negocio de las drogas, no será más que una suspensión que lo beneficiará.

7.2. Al renunciarse a la pena, de cierta manera también se renuncia a las penas accesorias y a las penas que no son privativas de libertad, pero que acompañan a estas últimas. Estas renuncias, generalmente obedecen a la imposibilidad de coaccionar el cumplimiento de estas penas o de fiscalizar su cumplimiento. Existe de cierto modo un cinismo del legislador, donde desde el punto de vista material se sabe o no puede menos que saberse que estos supuestos de penas no pueden ejecutarse.

Mayor es el problema con la víctima del delito, el desprecio a ella es de tal magnitud, que no sólo se prescinde de la pena en aras de la consecución de fines absolutamente ajenos, sino que se renuncia a la posibilidad de que la víctima sea reparada de todos los efectos perniciosos del delito. La víctima ya no sólo es ajena al proceso penal, sino también de sus consecuencias.

Indirectamente, también se incita a la víctima a renunciar a la posibilidad de denunciar el delito por razones de abandono, pues al tener conocimiento que sus pretensiones de reparación -civil y penal- no serán satisfechas, se generará un efecto de contramotivación que la disuadirá de denunciar los delitos que la afecten.

7.3. Por último, una propuesta de lege ferenda no puede ir en otra línea que no sea la necesidad de volver al anterior Derecho penal donde las penas debían ejecutarse independientemente del sexo, edad, raza o circunstancias personales del penado. Si la política de extranjería para el control de los flujos migratorios tratándose del caso español o la debida administración carcelaria en el caso chileno, hace necesario servirse de la institución de la expulsión, ella sólo debe existir en el marco del Derecho 
Polít. crim. Vol. 6, No 11 (Julio 2011), Art. 4, pp. 106 - 141.

[http://www.politicacriminal.cl/Vol_06/n_11/Vol6N11A4.pdf]

administrativo sancionador. Nada obsta a que se cumpla la pena y luego se expulse administrativamente al condenado por no concurrir a su respecto los requisitos legales para que permanezca en España o en Chile. Este criterio, sólo se puede flexibilizar en la medida que se garantice a la víctima y a la sociedad, que la sanción será cumplida en el país de procedencia del penado conforme a los Convenios suscritos o que se suscriban al efecto, y que existirá la debida reparación de la víctima. 
SALINERO, Sebastián. "La expulsión de extranjeros en el derecho penal. Una realidad en España, una posibilidad en Chile".

\section{BIBLIOGRAFÍA}

ASUA BATARRITA, Adela, "La expulsión del extranjero como alternativa a la pena: incongruencias de la subordinación del Derecho penal a las políticas de la inmigración", en LAURENZO COPELLO, Patricia (Coord.), Inmigración y Derecho penal: Bases para un debate, Valencia: Tirant, 2002.

BAUCELLS I LLADÓS, Joan, "El derecho penal ante el fenómeno inmigratorio", Revista de Derecho y Proceso Penal, No 13 (2005), pp. 45-61.

BRANDARIZ GARCÍA, José Ángel, Politica Criminal de la Exclusión. El Sistema Penal en Tiempos de Declive del Estado Social y de Crisis del Estado-Nación, Granada: Comares, 2007.

CANCIO MELIÁ, Manuel; MARAVER GÓMEZ, Mario, "El derecho penal español ante la inmigración: Un estudio político criminal", en BACIGALUPO, Silvina; CANCIO MELIÁ, Manuel (Coord.), Derecho Penal y Política Transnacional, Barcelona: Atelier, 2005, pp. 343-415.

CUGAT MAURI, Miriam, "La expulsión de extranjeros: política migratoria y funciones del Derecho Penal", Revista de Derecho y proceso penal, № 6 (2001), pp. 2337.

CURY URZUA, Enrique, Derecho penal. Parte General. Ed.8․ Santiago: Universidad Católica de Chile, 2005.

DE LUCAS, Javier, "Nuevas Estrategias de Estigmatización. El derecho frente a los inmigrantes", en PORTILLA CONTRERAS, Guillermo (Coord.), Mutaciones del Leviatán. Legitimación de los nuevos modelos penales, Madrid: Akal, 2005.

DÍAZ Y GARCÍA CONLLEDO, Miguel, Protección y expulsión de extranjeros en Derecho penal, Madrid: La Ley, 2007.

DÍEZ RIPOLLÉS, José Luis, Derecho Penal Español. Parte General. En esquemas. Valencia: Tirant, 2007.

ETCHEBERRY, Alfredo, Derecho penal. Parte General. T ${ }^{\mathrm{o}}$ II. Ed. $3^{\circ}$, Santiago: Editorial Jurídica de Chile, 2004.

FLORES MENDOZA, Fátima, "La expulsión del extranjero en el Código Penal español”, en LAURENZO COPELLO, Patricia (Coord.), Inmigración y Derecho penal: Bases para un debate, Valencia: Tirant, 2002.

GARRIDO MONTT, Mario, Derecho penal. Parte General. T. I. Ed. 2º, Santiago: Editorial Jurídica de Chile, 2009.

GIMÉNEZ-SALINAS, Esther, "Extranjeros en prisión", Cuadernos del Instituto Vasco de Criminología, No 7 Ex. (1994), pp. 133-146.

GRACIA MARTÍN, Luis; ALASTUEY DOBON, Ma Carmen, en GRACIA MARTÍN, Luis (coord.), Lecciones de consecuencias jurídicas del delito, Valencia: Tirant, $3^{\circ} \mathrm{Ed} ., 2004$.

IZQUIERDO ESCUDERO, Francisco Javier, "Naturaleza jurídica de la sustitución prevista en el artículo 89 del Código Penal: comentario al auto del Tribunal Constitucional 106/1997 de 17 de abril", La Ley: Revista jurídica española de doctrina, jurisprudencia y bibliografía, No 5 (1997), pp. 1861-1865.

LAFONT NICUESA, Luis, "La expulsión de extranjeros", en Cuadernos penales José María Lidon, U. De Duesto, Bilbao, 2004.

LAURENZO COPELLO, Patricia, "Ultimas reformas en el derecho penal de extranjeros: Un nuevo paso a la política de exclusión", Revista Jueces para la Democracia, No 50 (2004), pp. 30-35.

MAPELLI CAFFARENA, Borja, Las consecuencias jurídicas del delito, $4^{\circ}$ Ed., Madrid: Civitas, 2005. 
Polít. crim. Vol. 6, No 11 (Julio 2011), Art. 4, pp. 106 - 141.

[http://www.politicacriminal.cl/Vol_06/n_11/Vol6N11A4.pdf]

MELÓN MUÑOZ, Alfonso, "La expulsión del territorio nacional en el ámbito de la extranjería", Manuales de formación continuada, № 39 (2006), pp. 75-118.

MIRÓ LLINARES, Fernando, "Política comunitaria de inmigración y Política criminal en España. ¿Protección o "exclusión" penal del inmigrante", RECPC, 10-05 (2008), pp. 1-31, p. 22. en http://criminet.ugr.es/recpc/10/recpc10-05.pdf

MONCLÚS MASÓ, Marta, "Hacia una política criminal diferenciada para los extranjeros: la consolidación de la expulsión como sanción penal especial”, en RIVERA BEIRAS, Iñaki (Coord.), Política criminal y sistema penal: viejas y nuevas racionalidades punitivas, Barcelona: Anthropos, 2005, pp. 330-347.

MUÑOZ CONDE, Francisco; GARCÍA ARÁN, Mercedes, Derecho Penal. Parte General, $7^{\circ}$ Ed, Valencia: Tirant, 2007.

MUÑOZ LORENTE, José, "La expulsión del extranjero como medida sustitutiva de las penas privativas de libertad: el artículo 89 del CP tras su reforma por la ley orgánica 11/2003", Revista de Derecho Penal y Criminología, No Extra 2 (2004), pp. 401-482.

NAVARRO CARDOSO, Fernando, "Expulsión "penal" de extranjeros: una simbiosis de derecho penal "simbólico" y derecho penal del "enemigo"”, Revista de Derecho Penal y Criminología, No 17 (2006), pp. 153-182.

NOVOA MONREAL, Eduardo, Curso de Derecho penal Chileno. Parte General. Tomo II. Ed. $3^{\circ}$. Santiago: Editorial Jurídica de Chile, 2010.

POLAINO NAVARRETE, Miguel, La reforma penal española de 2003. Una valoración crítica, Madrid: Tecnos, 2004.

POLITOFF, Sergio, MATUS, Jean Pierre, RAMIREZ, María Cecilia, Lecciones de derecho penal chileno. Parte General. Ed ${ }^{\circ}$ 2. Santiago: Editorial Jurídica de Chile, 2006.

PORTILLA CONTRERAS, Guillermo, El derecho penal entre el cosmopolitismo universalista y el relativismo posmodernista, Valencia: Tirant, 2007.

QUINTERO OLIVARES, Gonzalo (Dir.), Comentarios al nuevo Código Penal, Pamplona: Aranzadi, 1996.

RÍOS CORBACHO, José Manuel, "Regulación jurídica de la extranjería: situación actual”, en RUÍZ RODRÍGUEZ, Luis Ramón (Coord.), Sistema penal y exclusión de extranjeros, Albacete: Bomarzo, 2006, pp. 67-103.

RODRÍGUEZ CANDELA, José Luis, "La expulsión del extranjero en el nuevo Código Penal", Revista Jueces para la Democracia, No 33 (1998), pp. 59-70.

RODRÍGUEZ MESA, $\mathrm{M}^{\mathrm{a}}$ José. "El sistema penal ante el reto de la inmigración clandestina. Funciones instrumentales y simbólicas", en PÉREZ ÁLVAREZ, Fernando (Ed.), Serta in Memoriam Alexandri Baratta, Salamanca: Universidad de Salamanca, 2004, pp. 845-869.

ROSA CORTINA, José Miguel, "La expulsión de los extranjeros no residentes legalmente condenados a pena privativa de libertad inferior a seis años tras la reforma 11/2003, de 29 de septiembre", La Ley: Revista jurídica española de doctrina, jurisprudencia y bibliografía, No 3 (2004), pp. 1917-1927.

ROXIN, Claus, Derecho Penal Parte General. Fundamentos. La Estructura de la Teoría del Delito. Traducido: LUZÓN PEÑA, Diego Manuel; DÍAZ Y GARCÍA CONLLEDO, Miguel; DE VICENTE REMESAL, Javier, Tomo I, España: Civitas, 2007.

SAGARRA TRÍAS, Eduard, "Un nuevo Status de extranjero en España (el inmigrante, irregular, empadronado, residente trabajando y con orden de expulsión)", Revista de Derecho migratorio y extranjería, No 1 (2002), pp. 89-97. 
SALINERO, Sebastián. "La expulsión de extranjeros en el derecho penal. Una realidad en España, una posibilidad en Chile”.

SANZ MORÁN, Ángel, "Reflexión de urgencia sobre las últimas reformas de la legislación penal", Revista de Derecho Penal, No 11 (2004), pp. 11-40.

SOUTO GARCÍA, Eva María, "Algunas notas sobre la función del derecho penal en el control de los flujos migratorios: especial referencia a la medida de expulsión", en FARALDO, Patricia; PUENTE, Luz María; SOUTO, Eva María (Coord.), Derecho penal de excepción: terrorismo e inmigración, Valencia: Tirant, 2007, pp. 289-322.

TERRADILLOS BASOCO, Juan, "Sistema Penal e Inmigración”, en PÉREZ ÁlVAREZ, Fernando (Ed.), Serta in Memoriam Alexandri Baratta, Salamanca: Universidad de Salamanca, 2004, pp. 1463-1481.

"Las políticas penales europeas de inmigración", en RUÍZ RODRÍGUEZ, Luis Ramón (Dir.), Respuestas Internacionales a los retos de la seguridad, Valencia: Tirant, 2009.

TORRES FERNÁNDEZ, María Elena, "La expulsión de extranjeros condenados a penas privativas de libertad inferiores a seis años. Comentario de la STS de 8 de julio de 2004 a propósito de la reforma operada por la LO 11/2003", Revista del poder judicial, $\mathrm{N}^{\mathrm{o}} 76$ (2004), pp. 231-245. 